\title{
Managing fire risk during drought: the influence of certification and El Niño on fire-driven forest conversion for oil palm in Southeast Asia
}

\author{
Praveen Noojipady ${ }^{1,2}$, Douglas C. Morton ${ }^{1}$, Wilfrid Schroeder ${ }^{2}$, Kimberly M. Carlson ${ }^{3}$, \\ Chengquan Huang ${ }^{2}$, Holly K. Gibbs ${ }^{4}$, David Burns ${ }^{5}$, Nathalie F. Walker ${ }^{5}$, and Stephen D. Prince ${ }^{2}$ \\ ${ }^{1}$ NASA Goddard Space Flight Center, Greenbelt, MD 20771, USA \\ ${ }^{2}$ Department of Geographical Sciences, University of Maryland, College Park, MD 20742, USA \\ ${ }^{3}$ Department of Natural Resources and Environmental Management, University of Hawai'i, Honolulu, \\ HI 96822, USA \\ ${ }^{4}$ Department of Geography and the Nelson Institute for Environmental Studies, University of Wisconsin, \\ Madison, WI 53726, USA \\ ${ }^{5}$ National Wildlife Federation, National Advocacy Center, Washington, DC 20006, USA
}

Correspondence to: Praveen Noojipady (praveen.noojipady@nasa.gov)

Received: 3 January 2017 - Discussion started: 9 January 2017

Revised: 18 July 2017 - Accepted: 22 July 2017 - Published: 21 August 2017

\begin{abstract}
Indonesia and Malaysia have emerged as leading producers of palm oil in the past several decades, expanding production through the conversion of tropical forests to industrial plantations. Efforts to produce "sustainable" palm oil, including certification by the Roundtable on Sustainable Palm Oil (RSPO), include guidelines designed to reduce the environmental impact of palm oil production. Fire-driven deforestation is prohibited by law in both countries and a stipulation of RSPO certification, yet the degree of environmental compliance is unclear, especially during El Niño events when drought conditions increase fire risk. Here, we used time series of satellite data to estimate the spatial and temporal patterns of fire-driven deforestation on and around oil palm plantations. In Indonesia, fire-driven deforestation accounted for one-quarter of total forest losses on both certified and noncertified plantations. After the first plantations in Indonesia received RSPO certification in 2009, forest loss and fire-driven deforestation declined on certified plantations but did not stop altogether. Oil palm expansion in Malaysia rarely involved fire; only $5 \%$ of forest loss on certified plantations had coincident active fire detections. Interannual variability in fire detections was strongly influenced by El Niño and the timing of certification. Fire activity during the 2002, 2004, and 2006 El Niño events was similar among oil palm plantations in Indonesia that would later become certified, noncertified plantations, and surrounding areas. However, total fire activity was $75 \%$ and $66 \%$ lower on certified plantations than noncertified plantations during the 2009 and 2015 El Niño events, respectively. The decline in fire activity on certified plantations, including during drought periods, highlights the potential for RSPO certification to safeguard carbon stocks in peatlands and remaining forests in accordance with legislation banning fires. However, aligning certification standards with satellite monitoring capabilities will be critical to realize sustainable palm oil production and meet industry commitments to zero deforestation.
\end{abstract}




\section{Introduction}

Global production of agricultural commodities such as palm oil has risen steadily in recent decades in response to market demand (USDA, 2009, 2010, 2016). Southeast Asia's palm oil sector has grown through expansion of oil palm plantations in Malaysia, Indonesia, and more recently, Papua New Guinea (Gunarso et al., 2013; Carlson et al., 2013; Miettinen et al., 2016a; Vijay et al., 2016). By 2014, Indonesia and Malaysia accounted for nearly $69 \%$ of harvested oil palm area worldwide (FAO, 2016).

In the past decade, Indonesia had the highest rate of forest loss of any country in Southeast Asia (Hansen et al., 2013; Margono et al., 2014; Kim et al., 2015), spurred by rapid forest conversion for oil palm and other industrial plantations (Carlson et al., 2012; Gunarso et al., 2013; Abood et al., 2015). Between 1990-2010, more than one-third of new oil palm plantations replaced forested landscapes in Southeast Asia (Gunarso et al., 2013; Gaveau et al., 2016), with rates as high as $90 \%$ in regional hotspots such as coastal West Kalimantan, Indonesia (Carlson et al., 2013). Conversion of primary and logged forests for oil palm, including vast areas with deep organic peat soils, contributed to significant greenhouse gas (GHG) emissions from fire, decomposition, and peat oxidation (Page et al., 2002; van der Werf et al., 2008; Hooijer et al., 2012; Ramdani and Hino, 2013; Field et al., 2016; Huijnen et al., 2016). Environmental concerns with palm oil production extend beyond GHG emissions, however, as forest loss threatens biodiversity (Pimm et al., 2014; Vijay et al., 2016) and particulate emissions from fires are a major public health concern in Indonesia and downwind population centers such as Singapore (Murdiyarso et al., 2004; Gaveau et al., 2014; Kunii et al., 2002; Reddington et al., 2014; Marlier et al., 2015; Chisholm et al., 2016; Johnston et al., 2015).

Palm oil is the fastest growing certified agriculture commodity, and Indonesia accounted for $>50 \%$ of certified production areas in 2016 (Potts et al., 2014; RSPO, 2016). The push for certification within the palm oil industry reflects a growing consumer awareness of GHG emissions from palm oil expansion and peat oxidation and an overall rise in producer and consumer interest in "sustainable" and deforestation-free products (UNCS, 2014; Butler, 2015; McCarthy et al., 2016). The Roundtable on Sustainable Palm Oil (RSPO) certification is the most widely adopted certification standard. By 2016, the RSPO had certified 2.83 Mha of oil palm that produced 10.8 million tons of palm oil, or approximately $17 \%$ of global palm oil production, with $>90 \%$ of certified areas in Southeast Asia (RSPO, 2016). Specific principles and criteria of RSPO certification promote sustainable palm oil production and processing (Garrett et al., 2016; RSPO, 2004, 2015b). Among other provisions, RSPO certification prohibits conversion of primary forests and forests with a high conservation value (HCV) and bans fire use for land clearing in compliance with the
Indonesian moratorium on fire (RSPO, 2007; RSPO, 2013; Edwards and Heiduk, 2015). Companies interested in certification first become members of the RSPO and are subjected to the principles and criteria $(\mathrm{P} \& \mathrm{C})$, including the prohibition on new plantings through deforestation of primary or HCV forests after November 2005 without compensation (Criterion 7.3, RSPO, 2013). However, the RSPO does not independently monitor deforestation within member plantations. RSPO member companies are notified of satellite fire detections on their plantations, and a description of fire incidents is included in monthly reports to RSPO. Recent fire activity has been assessed for a subset of palm oil concessions in Indonesia (Cattau et al., 2016a), but the use of fire for forest conversion on oil palm plantations has not previously been quantified.

Improving estimates of fire-driven deforestation is critical for assessing environmental compliance by oil palm plantations, reducing uncertainties in deforestation carbon emissions (Le Quéré et al., 2015; Houghton et al., 2012; van der Werf et al., 2009b), and characterizing ignition sources that may give rise to uncontrolled burning during drought periods (Carlson et al., 2012; Cattau et al., 2016b). The timing of GHG emissions from forest conversion to oil palm depends on the degree of fire use for deforestation (DeFries et al., 2008; Houghton et al., 2012), including the proportion of clearing activity through fire and the combustion completeness of initial or repeated burning (van der Werf et al., 2009a). Fires are common in industrial plantations and smallholder properties (Stolle et al., 2003; Austin et al., 2015; Marlier et al., 2015; Miettinen et al., 2016b; Cattau et al., 2016a), yet the link between fire activity and forest conversion is unclear. Many estimates of carbon emissions from tropical forest conversion report committed fluxes without separating fire and decomposition losses (Koh et al., 2011; Carlson et al., 2012; Austin et al., 2015). Previous studies with bookkeeping or biogeochemical models suggest that fire accounts for $30 \%$ (Houghton and Hackler, 1999) to $50 \%$ (van der Werf et al., 2009a) of carbon emissions from aboveground biomass during forest conversion in Southeast Asia a broad range that applies to all forest conversion, not strictly to oil palm expansion. Fires are not restricted to forested areas; El Niño conditions suppress precipitation over large parts of Southeast Asia, leading to widespread fire activity during drought periods, particularly in carbon-rich peatlands (Page et al., 2002; van der Werf et al., 2008; Field et al., 2009, 2016). Understanding the contribution from fire-driven deforestation to total fire activity is therefore a critical part of mitigating fire risk during drought years (e.g., Chen et al., 2016).

Here, we combined time series of satellite data on forest loss and active fire detections with locations of oil palm plantations to assess fire-driven forest and peatland conversion on and around oil palm plantations. The combination of land management, forest loss, and active fire data provided an opportunity to evaluate the relative contributions from different 
fire types to spatial and temporal variability in satellite fire detections. Our study addressed three primary questions regarding oil palm expansion (1) What fraction of forest and peat forest conversion for oil palm involves fire? (2) Does certification alter fire use for forest conversion or the frequency of management or accidental fires in plantation areas? (3) During El Niño years, do certified plantations have fewer satellite fire detections compared to noncertified plantations and surrounding lands? Characterizing fire-driven deforestation is critical to evaluating the influence of RSPO certification on fire activity and to improving estimates of GHG emissions from oil palm expansion.

\section{Material and methods}

\subsection{Oil palm plantations}

The government of Indonesia allocates land for oil palm production to companies for a limited period of time. We separated leases for oil palm production into two categories, certified and noncertified plantations. Certified plantations are properties certified by the RSPO; noncertified plantations are properties allocated by the Indonesian government to companies but that are not certified, even if they are held by RSPO members. Comparisons between certified (ever) and noncertified (never) plantations considered forest loss and fire activity over three timescales: (1) following the benchmark date for compliance with RSPO criterion 7.3 (November 2005), (2) following the first issuance of RSPO certificates to Indonesian producers in 2009, and (3) following the date of certification for individual plantations. Boundaries of certified plantations were compiled from several sources, including boundary polygons provided by the RSPO, digitized boundaries from RSPO audit reports, and spatial data on plantation boundaries from RSPO member companies provided in annual communication of progress (ACOP) reports (RSPO, 2015a). Boundaries of noncertified plantations were obtained from a database of oil palm plantations published by Greenpeace (Greenpeace, 2016) and supplemented with noncertified plantations held by RSPO members, as indicated in ACOP reports (RSPO, 2015a) or by Sawit Watch (2013). In total, we analyzed 154 certified and 1536 noncertified plantation boundaries for Indonesia (Fig. 1). Data on the location and certification date of certified plantations were also available for Malaysia $(n=119)$ and Papua New Guinea $(n=10)$, but boundaries of noncertified plantations were not available.

We used maps of planted oil palm to identify established plantations within certified and noncertified plantations in Indonesia, Malaysia, and Papua New Guinea. Data on the extent of planted oil palm were compiled from three sources: Gunarso et al. (2013) for 2000, 2005, and 2010; Carlson et al. (2013) for 2000, 2005, and 2010; and Transparent World (TW, 2015) for 2014. Maps of planted palm were generated from $30 \mathrm{~m}$ Landsat imagery and validated using higher- resolution satellite imagery (Carlson et al., 2013; TW, 2015; Petersen et al., 2016). When multiple estimates were available for the same epoch, we used the combined area from all sources as a more conservative estimate of the extent of planted oil palm. Only noncertified plantations that showed evidence of planted oil palm up to 2014 were included in this study.

We evaluated forest loss and fire activity for a single set of $5 \mathrm{~km}$ buffers surrounding both certified and noncertified plantations in Indonesia. Recent fire emergencies have intensified the debate over the source of fire ignitions during El Niño and other drought events (e.g., Austin et al., 2015). The $5 \mathrm{~km}$ buffer was chosen to capture the potential influence of forest loss and fire activity on the surrounding landscape, including the direct fire spread from adjacent lands into palm oil plantations, wind-blown embers from nearby fires, and the most acute impacts of smoke on both human health and ecosystems. Oil palm plantations in Southeast Asia are frequently adjacent to other oil palm plantations (Fig. 1), making it difficult to attribute buffer activities to only certified or noncertified neighbors. We therefore analyzed a single set of buffer areas to evaluate forest loss and fire activity surrounding large oil palm plantations. Nearly $12 \%$ of the area within the $5 \mathrm{~km}$ buffer was mapped as planted oil palm in $2010(\mathrm{Gu}-$ narso et al., 2013; Carlson et al., 2013). As for plantations, areas of planted oil palm were excluded from estimates of forest loss in buffer areas. However, total fire activity in the buffer region may reflect differences in oil palm management, in addition to differences in land use and land cover, based on the abundance of planted palm outside of the large certified and noncertified plantations.

\subsection{Forest definition, cover, and loss}

Estimates of forested area and forest loss fundamentally depend on the definition of forest cover (Sexton et al., 2016). Countries may use canopy cover thresholds between 10 and $30 \%$ for reporting under the United Nations Framework Convention on Climate Change (UNFCCC) REDD+ framework (UNFCCC, 2002). The Indonesian government uses two definitions of forest for reporting purposes (BP-REDD+, 2015). For the United Nations Food and Agriculture Organization (FAO) Forest Resources Assessments (FRAs), forest is defined as canopy cover $>10 \%$ for Global Forest Resource Assessment (FAO, 2010), whereas the Minister of Forestry Decree uses a higher threshold of canopy cover $>30 \%$ for forest reference emissions level (FREL) reporting (MoF, 2008), at the high end of the REDD+ range. Therefore, we used the $>30 \%$ canopy cover threshold in this study to be consistent with the forest definition used by the Indonesian government. The higher canopy cover threshold also reduced ambiguity associated with discriminating tropical forests from other land cover types in remote sensing data for regions with persistent cloud cover, such as Southeast Asia. Forest and non-forest areas were separated using Landsat- 


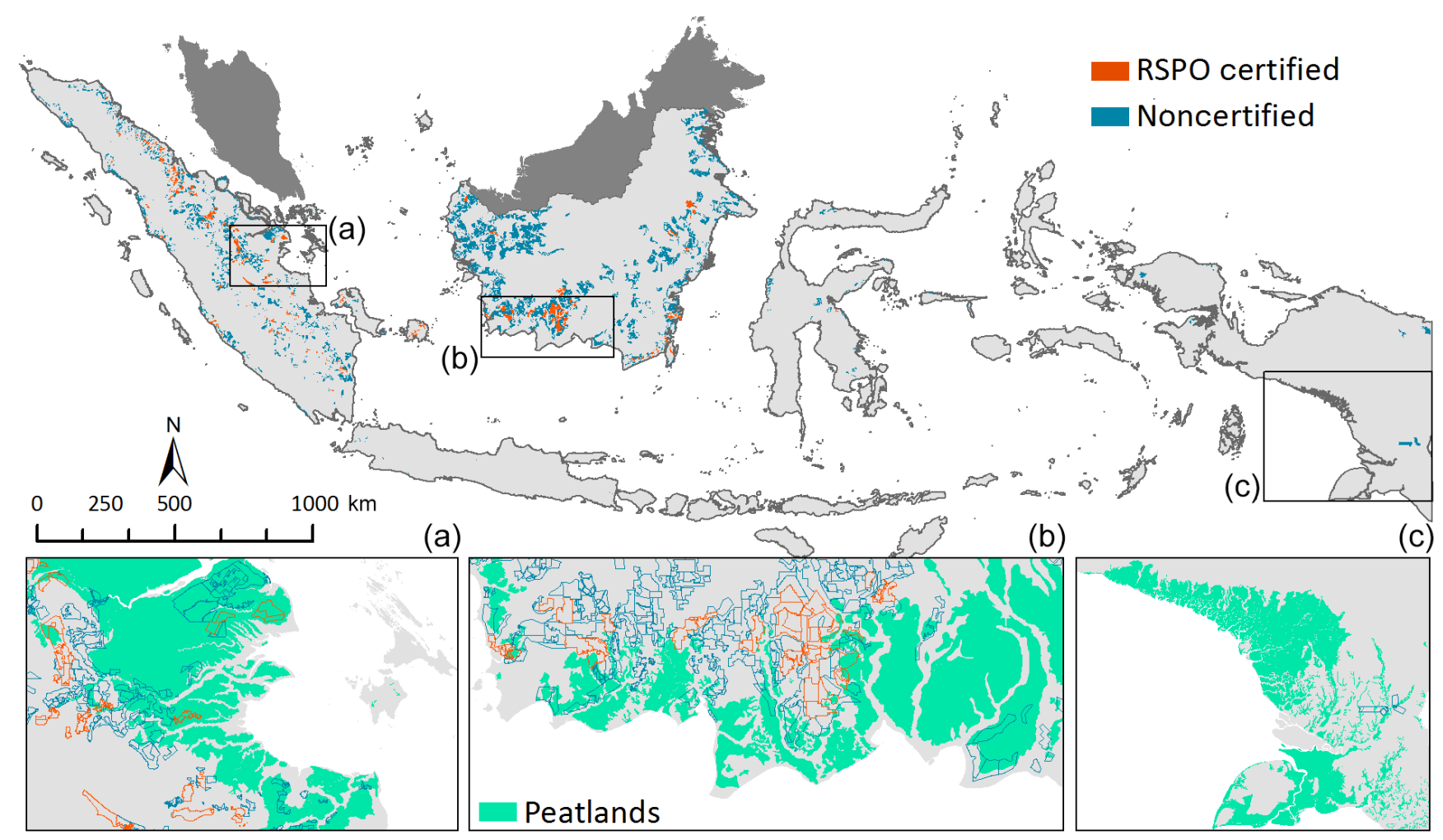

Figure 1. Extent of RSPO certified (red) and noncertified (blue) oil palm plantations in Indonesia. Regional subsets highlight plantation boundaries on peatlands (green) in the lowlands of Sumatra (a), Kalimantan (b), and Papua (c).

based estimates of fractional tree cover in 2000 (Hansen et al., 2013). Estimates of annual forest loss between 2002 and 2014 (Hansen et al., 2013) were used to identify the timing of forest conversion on and around plantations.

\subsection{Active fires}

We used the time series of active fire detections from the Moderate Resolution Imaging Spectroradiometer (MODIS) instruments on NASA's Terra and Aqua satellites to evaluate the spatial and temporal patterns of daily fire activity during 2002-2015. The global monthly fire location product (MCD14ML) identifies the location of actively burning fires and thermal anomalies at the time of satellite overpass at $1 \mathrm{~km}$ nominal spatial resolution (Giglio et al., 2003). Fire pixel counts from Terra and Aqua MODIS sensors were combined using a $1 \mathrm{~km}$ grid to evaluate monthly and annual fire activity from 2002 to 2015 . We compared fire pixel density $\left(\mathrm{km}^{-2}\right)$ across certified plantations, noncertified plantations, and a $5 \mathrm{~km}$ buffer region surrounding both certified and noncertified plantations.

For 2014 and 2015, active fire detections with higher spatial resolution were used to confirm patterns in $1 \mathrm{~km}$ MODIS fire data. These complementary active fire detections were derived from the Visible Infrared Imaging Radiometer Suite (VIIRS) I-Band (375 m) on the Suomi National Polar- orbiting Partnership (S-NPP) (Schroeder et al., 2014) and Landsat-8 Operational Land Imager (OLI) data at $30 \mathrm{~m}$ resolution (Schroeder et al., 2015). The finer spatial resolution of these fire data capture additional details regarding fire activity that can be difficult to evaluate at MODIS resolution, including the precise location of active fire fronts, separation of flaming and smouldering fires (Elvidge et al., 2015), and detection of small and/or lower-intensity fires (Schroeder et al., 2015) - an important component of fire activity in agricultural landscapes (Randerson et al., 2012). In this study, the improved spatial resolution of VIIRS and OLI fire data aided the attribution of active fires to specific land management areas.

\subsection{Fire-driven forest conversion for oil palm expansion}

We combined satellite remote sensing data on forest cover (2000; Hansen et al., 2013), forest cover change (20022014; Hansen et al., 2013), and active fire detections (20012014; Giglio et al., 2003) to identify fire-driven forest conversion on certified and noncertified plantations. Our assessment excluded forested areas identified as oil palm (Gunarso et al., 2013; Carlson et al., 2013). Deforestation on oil palm plantations was therefore limited to Hansen et al. (2013) tree cover loss in forested areas (tree cover $>30 \%$ ) outside of planted palm. Oil palm expansion into peat forests was as- 

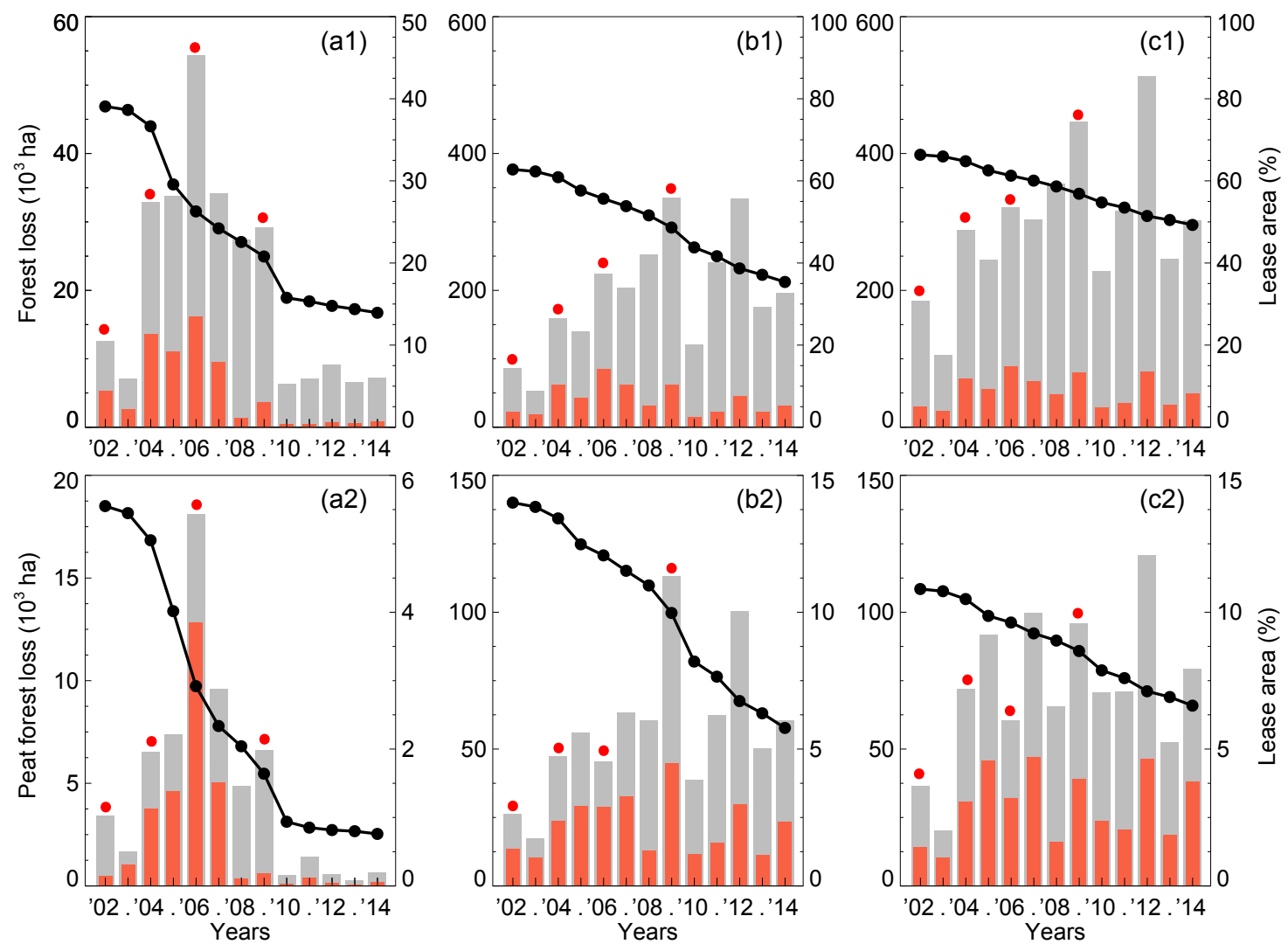

-: Certified :-

-: Noncertified :-

-: $5 \mathrm{~km}$ buffer :-

Forest loss

Fire-driven loss

Residual forest

Figure 2. Forest loss within the boundaries of (a) certified plantations, (b) noncertified plantations, and (c) the $5 \mathrm{~km}$ buffer region surrounding certified and noncertified plantations in Indonesia from 2002 to 2014. (a1-c1) Forest loss (grey) and fire-driven forest loss (orange); (a2-c2) peat forest loss (grey) and fire-driven peat forest loss (orange). Solid black lines indicate residual forest cover as a percentage of management areas. Annual estimates of total forest loss and fire-driven forest loss are summarized in Tables B2 and B3, including the proportion of forest losses on plantations after the receipt of RSPO certification. Orange dots indicate El Niño years.

sessed using peatland layers created by Wahyunto and Subagjo $(2003,2004)$ and Wahyunto et al. (2006) and Wetlands International (WI, 2016) (Fig. A1). Co-located forest loss and active fire detections were considered fire-driven deforestation. Given the potential for fire activity to predate the detection of forest loss (Morton et al., 2008), active fire data from the year of forest loss and 1 year before were combined to identify fire activity associated with forest conversion.

\section{Results}

\subsection{Certification and fire-driven deforestation}

In Indonesia, forest loss on and around oil palm plantations reduced remaining forest cover by $30-36 \%$ between 2002 and 2014 (Fig. 2). Gross forest loss on plantations but outside of planted palm areas totalled 3.59 Mha (Table 1). Average annual rates of forest loss were similar in certified $\left(1.25 \% \mathrm{yr}^{-1}\right)$ and noncertified plantations $\left(1.72 \% \mathrm{yr}^{-1}\right)$ over this period. However, trends in annual forest loss differed between certified plantations and both noncertified and buffer areas. Following the cutoff date for new deforestation (November 2005), rates of forest clearing actually increased on plantations that would later be certified (2006-2008, $38636 \mathrm{ha} \mathrm{yr}^{-1}$ ) before declining sharply after the first certificates were issued (2009-2015, $10943 \mathrm{ha} \mathrm{yr}^{-1}$; Table B2). Between 2009 and 2012, the majority of forest loss occurred on plantations that had not yet received RSPO certification (Table B2), whereas plantations with certificates accounted for most forest losses identified in 2013-2014. Patterns of peat forest loss on certified plantations were similar to lowland forest loss outside of peat (Fig. 2, Table B3), with a 
Table 1. Total and fire-driven forest loss for oil palm expansion in Indonesia from 2002 to 2014 within certified and noncertified plantations. See Tables B2 and B3 for annual estimates of total forest loss, fire-driven forest loss, and the proportion of forest losses on plantations after the receipt of RSPO certification.

\begin{tabular}{lrrrrr}
\hline & $\begin{array}{r}\text { Lease area } \\
\text { (ha) }\end{array}$ & $\begin{array}{r}\text { Planted palm by 2010 } \\
\text { (ha) }\end{array}$ & $\begin{array}{r}\text { Forest loss }^{\mathrm{a}} \\
\text { (ha) }\end{array}$ & $\begin{array}{r}\text { Peat forest loss } \\
\text { (ha) }\end{array}$ & $\begin{array}{r}\text { Fire-driven loss }^{\mathrm{b}} \\
\text { (ha) }\end{array}$ \\
\hline RSPO certified & 1652644 & 1212669 & 267931 & 61750 & $85524(26 \%)$ \\
Noncertified & 11266875 & 3416302 & 2522909 & 742025 & $810346(25 \%)$ \\
5 km buffer & 25092975 & 2931778 & 3853782 & 937206 & $1073664(22 \%)$ \\
\hline
\end{tabular}

${ }^{a}$ Forest loss outside of peat areas. ${ }^{\mathrm{b}}$ Combined (peat and non-peat) forest loss related to fire.

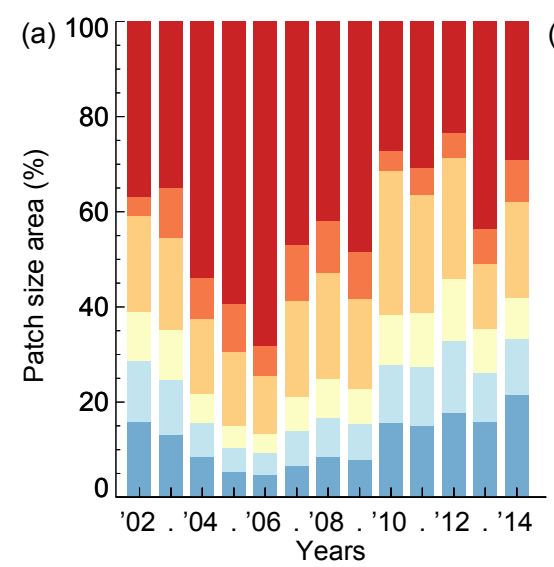

-: Certified :-

Patch size (ha)

$\begin{array}{ll}>100 & 5-10 \\ 50-100 & 2-5 \\ 10-50 & 0-2\end{array}$

(b)

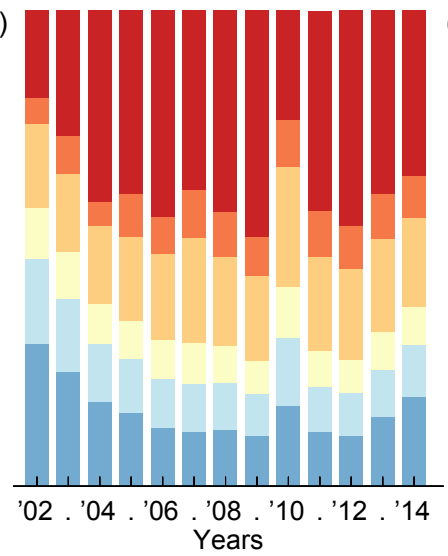

-: Noncertified :- (c)

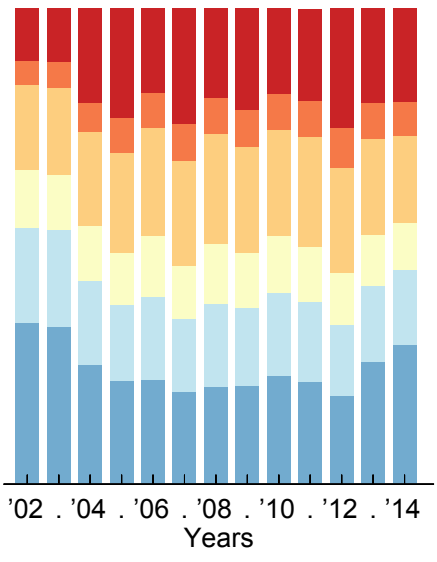

-: $5 \mathrm{~km}$ buffer :-

Figure 3. Forest loss patch size distribution in Indonesia within the boundaries of (a) RSPO certified plantations, (b) noncertified plantations, and (c) the $5 \mathrm{~km}$ buffer region. Patch sizes were assessed at the plantation level and summarized annually based on the proportion of total forest losses in each size category during 2002-2014.

peak in peat forest loss around the 2006 El Niño event followed by a steady decline after 2009. In contrast, rates of forest and peat forest loss on noncertified plantations increased over time, with peak clearing in 2009 and 2012 (Fig. 2, Tables B2, B3). Temporal patterns of forest loss for buffer areas within $5 \mathrm{~km}$ of plantations (both certified and noncertified) were similar to noncertified plantations. Given the larger extent of noncertified plantations, mean annual forest losses differed nearly 10 -fold between certified and noncertified plantations (20 610 and $194070 \mathrm{ha} \mathrm{yr}^{-1}$, respectively).

Although the use of fire for forest conversion is prohibited in Indonesia, satellite data suggest that one-quarter of forest clearing in both certified and noncertified plantations involved fire (Table 1). For certified plantations in Indonesia, the proportion of fire-driven deforestation in both lowland and peat forests declined sharply following the cutoff date for new deforestation (November 2005) but before the first RSPO certificates were issued (Fig. 2), from $37 \%$ during $2002-2005$ to $19 \%$ in $2006-2008$, and only $8 \%$ of all for- est loss was identified as fire-driven deforestation after the first certificates were issued (2009-2014; Tables B2, B3). More than one-third of Indonesian plantations that would later be certified had fire-driven deforestation between 2002 and 2007 (Table B4). As total deforestation declined from 2008 to 2014, fire-driven deforestation activity was still distributed across 34-50 plantations (22-32\%, Table B4). The proportion of fire-driven deforestation in noncertified plantations also declined over time, but not as rapidly as in certified plantations, especially in peat areas. Fire-driven forest losses accounted for $14 \%$ of total forest loss in noncertified and buffer areas from 2009-2014 (Table B2), but 34\% of peat forest loss was identified as fire-driven deforestation (Table B3). Notably, the proportion of fire-driven deforestation in El Niño years $(2002,2006,2009)$ was similar to or lower than non-El Niño years (e.g., 2003, 2007, 2010) for all three management types - certified plantations, noncertified plantations, and buffer areas. 

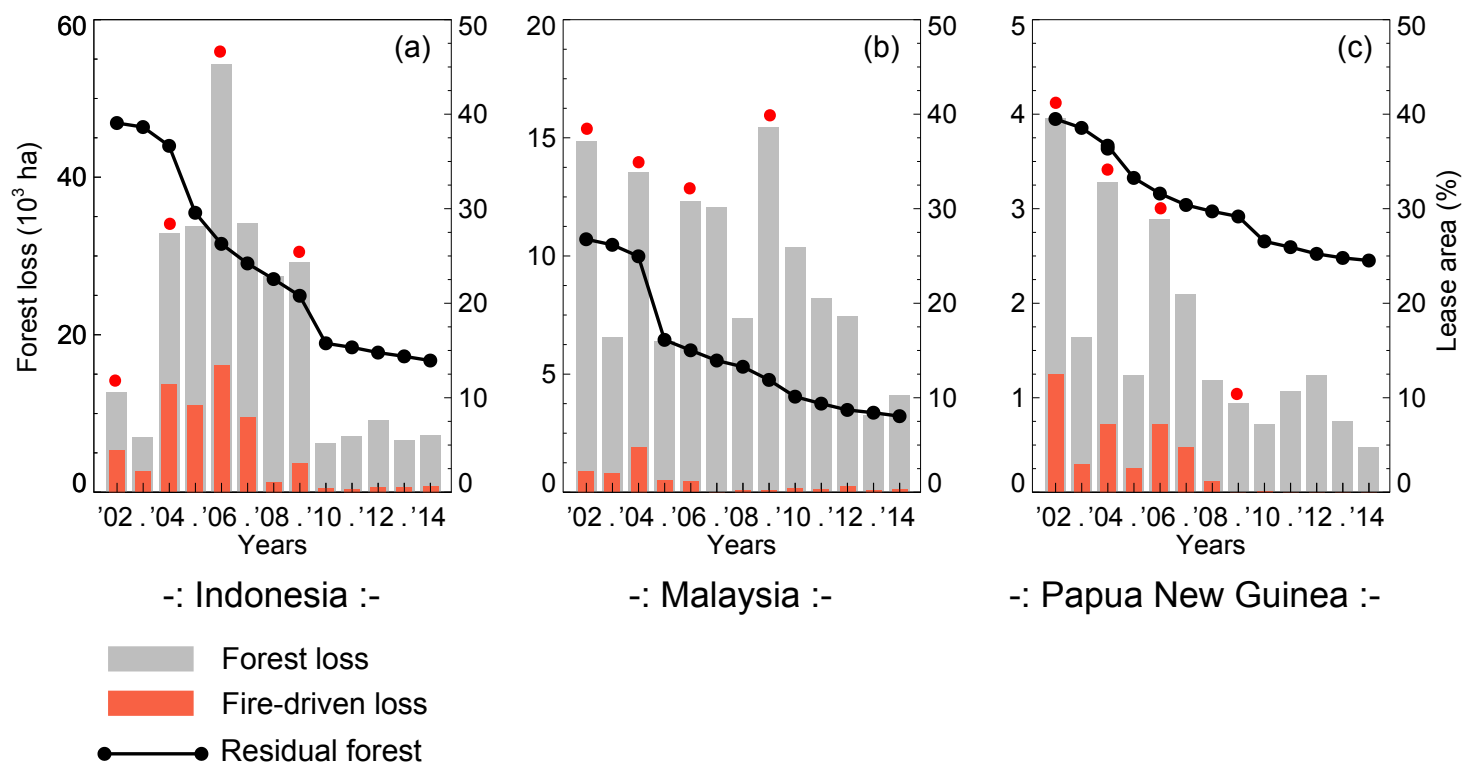

Figure 4. Total forest loss (grey) and fire-driven forest loss (orange) on certified plantations in (a) Indonesia, (b) Malaysia, and (c) Papua New Guinea. Forest loss was estimated outside of planted palm (Carlson et al., 2013; Gunarso et al., 2013). Black lines indicate remaining forest area as a fraction of the total lease area of certified plantations in each country. Annual estimates of total forest loss and fire-driven forest loss for certified plantations are summarized in Tables B2-B5, including the proportion of forest losses on plantations after the receipt of RSPO certification. Orange dots indicate El Niño years.

However, certification did not halt forest conversion altogether. In Indonesia, forest loss continued on certified plantations following the start of RSPO certification efforts, including fires for forest conversion, leading to an additional $8 \%$ loss of remaining forest cover between 2009 and 2014 (Fig. 2; Tables B2, B3, B4). Lower rates of forest loss on certified plantations are consistent with RSPO restrictions on clearing $\mathrm{HCV}$ forest areas and other lands deemed unsuitable for palm oil production. Declining rates of forest loss after 2009 may also reflect limited remaining forest cover on certified plantations by 2014 (15\%, Fig. 2), leading to smaller clearing sizes that are more difficult to assess with remote sensing data on forest loss and fire activity (Fig. 3). In contrast, the contribution from larger clearing sizes increased over time on noncertified plantations and remained stable for buffer areas.

Patterns of fire-driven forest loss on certified plantations differed across Indonesia, Malaysia, and Papua New Guinea (Fig. 4). Overall forest loss rates were higher in Indonesia than Malaysia and Papua New Guinea (Table B1). However, large forest clearing events were more common on certified plantations in Malaysia and Papua New Guinea, with more than two-thirds of forest loss in patches $>10$ ha (Fig. A2). Annual forest loss rates in Malaysia remained high following certification, with little change from pre-certification patterns (Fig. 4; Tables B5, B6). In Malaysia, oil palm expansion on certified plantations rarely involved fire, and only $5 \%$ of total forest loss was identified as fire-driven deforestation (Ta- bles B4, B5, B6). Fire detections associated with forest loss declined in all three countries following the start of certification in 2008-2009. In Malaysia and Papua New Guinea, plantations with RSPO certificates had little fire-driven deforestation and few total fire detections for land management (Tables B4-B7).

Certification decoupled fire detections from variability in fire risk driven by El Niño-Southern Oscillation in Indonesia. Interannual variability in Indonesian fire activity is largely governed by the timing and magnitude of El Niño events (Fig. A3; Chen et al., 2016). Prior to 2009, interannual variability in fire detections was similar for certified plantations, noncertified plantations, and buffer areas in Indonesia (Fig. 5). Mean fire rates across land management classes were also consistent during El Niño events in 2002, 2004, and 2006, with important contributions from fire-driven deforestation to total fire detections in these years. Following certification, fire activity declined in certified plantations in all years, with 75 and $66 \%$ fewer fires per square kilometer than noncertified plantations during the 2009 and 2015 El Niño events, respectively (Fig. 5, Table B6). Monthly fire counts confirmed the reduction in fire activity on certified plantations during peak burning months (August, September, October) of the 2009 and 2015 El Niño events (Fig. A4). Evidence for reduced fire activity on certified plantations highlights the potential for management of fire risk within oil palm plantations, even during strong El Niño drought conditions (Fig. A5). 

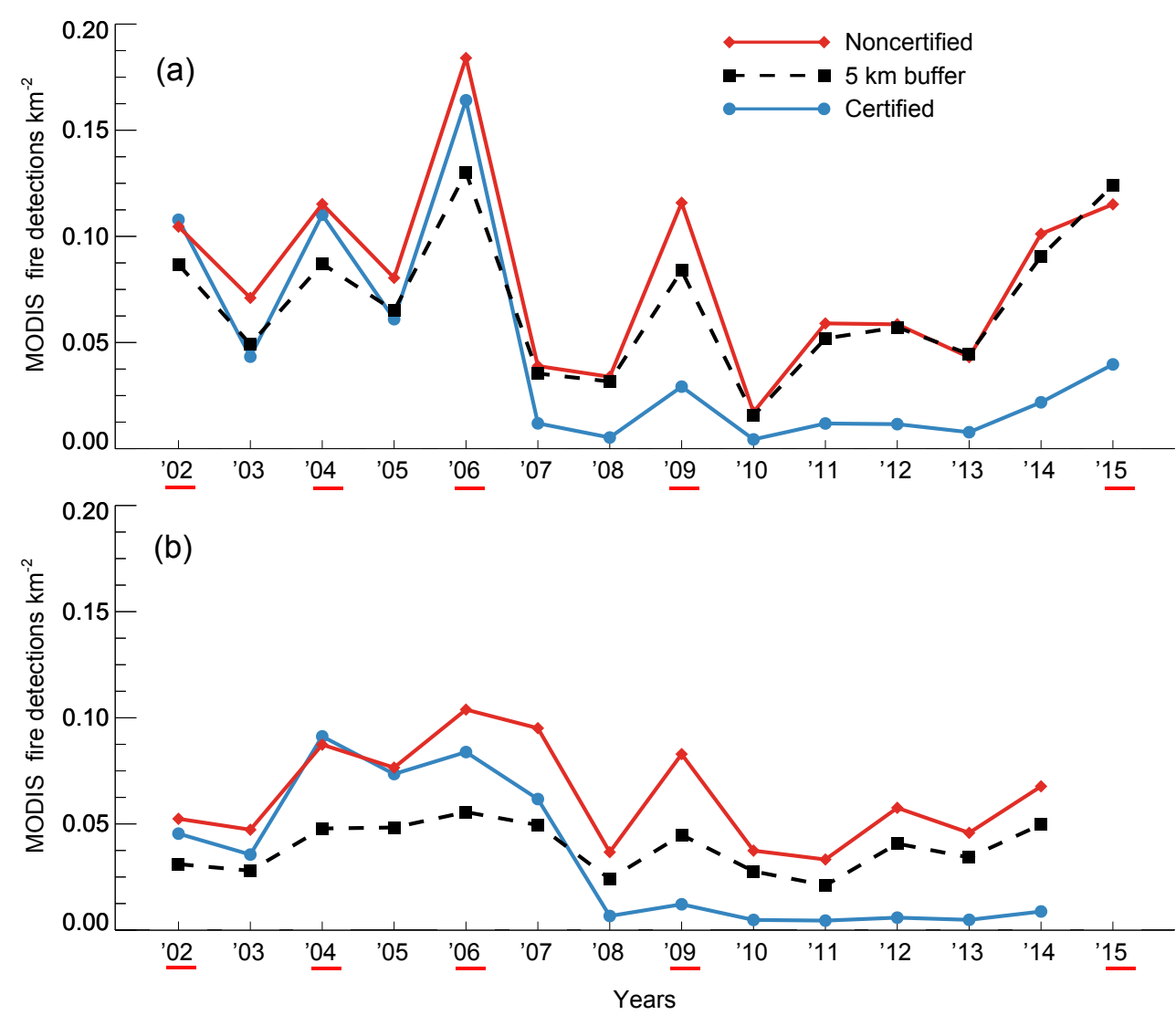

Figure 5. Density of MODIS active fire detections within certified plantations, noncertified plantations, and the $5 \mathrm{~km}$ buffer region around plantations in Indonesia from 2002 to 2014. (a) Time series of all MODIS active fire detections; (b) time series of MODIS active fire detections associated with fire-driven deforestation. El Niño years are underlined in red. Table B6 provides annual estimates of fire counts on certified and noncertified plantations, including the proportion of fire detections on plantations after the receipt of RSPO certification.

Attribution of fire activity is a critical component of satellite-based monitoring for environmental compliance. Higher-resolution active fire data from VIIRS $(375 \mathrm{~m})$ and Landsat 8/OLI $(30 \mathrm{~m})$ confirmed the relative decline in fire activity on certified plantations compared to noncertified plantations and buffer areas in both 2014 and 2015 (Fig. 6). The VIIRS $375 \mathrm{~m}$ fire data provided a more complete characterization of the fire perimeter than MODIS on a daily basis. Although less frequent, Landsat 8 coverage every 16 days captured the precise location of active fire fronts, small fires, and persistent smouldering in peat areas that may last for many days (Figs. 6 and A6). High-resolution fire data offer improved understanding of fire use for deforestation and agricultural management, with detections that can be more definitively attributed to specific actors in support of monitoring, reporting, and verification.

\section{Discussion}

Following the issuance of the first RSPO certificates in 2009, certified oil palm plantations in Indonesia had lower firedriven deforestation and total fire activity than noncertified plantations, including during El Niño events. These reductions point to the potential for RSPO to contribute to REDD+ and to decrease fire ignitions during drought conditions. Our findings of lower fire activity on certified plantations for both deforestation and land management during the 2009 and 2015 El Niño events contradicts earlier work by Cattau et al. (2016a) showing higher fire activity in a small subset of certified plantations, possibly due to a larger sample size of certified plantations in our study ( $N=154$ compared to 28 , with only four plantations on peat). However, certification did not halt forest losses or fire activity altogether, and rates of forest loss actually increased following the cutoff date for new deforestation but before the first RSPO certificates were issued. In addition, certified plantations currently account for a small fraction of total oil palm leases (e.g., $13 \%$ in Indonesia); noncertified plantations maintained higher rates of fire-driven deforestation and fire activity in recent years, including the 2015 El Niño. The opportunity therefore exists to enhance the environmental benefits of RSPO certification through expansion of certified plantations and strengthening of certification standards, including the use of satellite monitoring of fire activity and forest loss. 

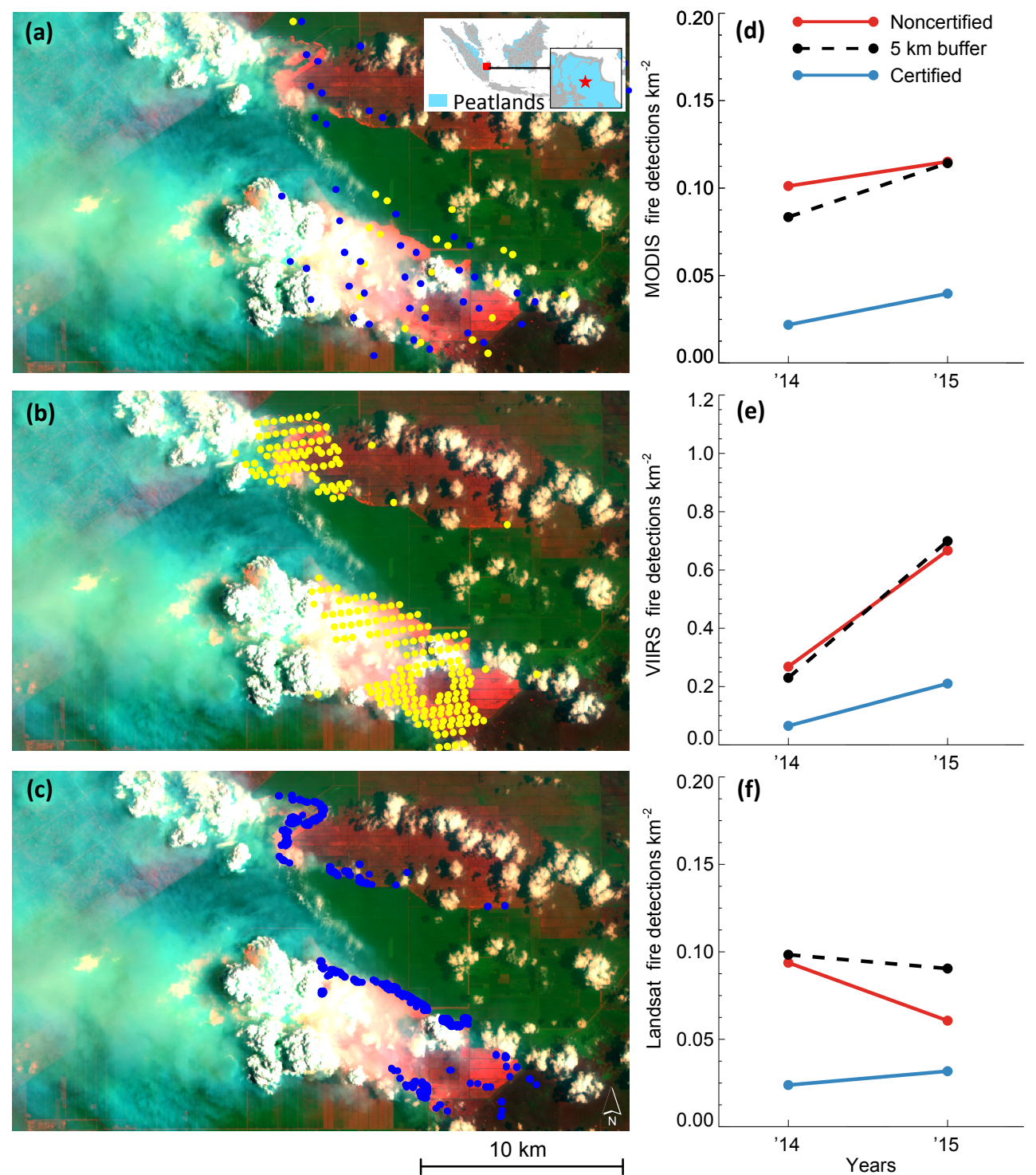

Figure 6. High-resolution active fire detections confirm lower fire activity on certified plantations during the 2015 El Niño event. Map panels show active fire detections on 30 September 2015 for peat fires in southern Sumatra from (a) Terra (blue) and Aqua (yellow) MODIS (1 km), (b) S-NPP/VIIRS (375 m), and (c) Landsat-8/OLI (30 m). Background images in (a-c) are a false-color composite of Landsat 8/OLI bands 7-5-3 from the same date (path/row: 124/62). Adjacent panels show total annual fire detections in 2014 and 2015 for certified plantations from (d) MODIS, (e) VIIRS, and (f) Landsat 8/OLI.

Our study confirmed the pervasive use of fire for forest conversion to oil palm in Indonesia, with one-quarter of forest loss identified as fire-driven deforestation. Fire-driven deforestation was less common on certified plantations in Malaysia and Papua New Guinea, and fire use for forest conversion declined to near zero after the start of certification in 2008-2009 in these countries. The long-term records of Landsat forest loss and MODIS fire detections provide robust evidence of changing fire use for land management on certified oil palm plantations.

Several factors may account for the reduction in fire activity on certified plantations following certification. First, certification may reduce fire-driven deforestation by directly influencing land management practices. Collectively, all certified plantations in Indonesia, Malaysia, and Papua New Guinea showed declines in fire-driven forest losses after 2009. Second, the observed decline in fire activity may indicate an end of the expansion process rather than a change in fire-driven deforestation. Remaining forest covered only $8-15 \%$ on certified plantations in Malaysia and Indonesia; remaining forest areas may not be suitable for oil palm or accessible based on RSPO restrictions. In a future study, it may be possible to control for differences in remaining forest cover, plantation age, or company management practices 
using a matched study design. For Indonesia, a reduction in overall fire activity may be less important for GHG emissions than a reduction in peat fires (e.g., van der Werf et al., 2008; Cattau et al., 2016a; Field et al., 2016). Regardless, the potential exists for RSPO to promote fire-free management of plantations to protect high-value tree crops and remaining carbon stocks in forests and peatlands. Large labor forces needed for oil palm production (Lambin et al., 2013) may aid regional fire suppression efforts, allowing established plantations to maintain lower fire activity on and around plantations during El Niño years.

The proportion of fire-driven deforestation on oil palm plantations in Indonesia $(\sim 25 \%)$ was similar to the estimate of combustion losses in bookkeeping models (30-40\%; Houghton and Hackler, 1999), but fire use was much lower in Malaysia and Papua New Guinea. However, our study only confirms the coincident timing and locations of fires and forest losses, not the combustion completeness of fires for forest conversion. Removal of forest vegetation is critical for establishing an oil palm plantation, but combustion completeness may be lower for these fires, given higher fuel moisture and less need for complete combustion of aboveground biomass than for expansion of row crop agriculture (Morton et al., 2008). Fuel moisture also has a substantial influence on trace gas emissions from fire, including smouldering fires in peatlands (Miettinen et al., 2012; Page and Hooijer, 2016). By combining active fire detections with satellite observations of trace gas emissions, it may be possible to characterize regional GHG emissions directly associated with fires on oil palm plantations. Complementary data on trace gas emissions may also compensate for missing satellite fire detections. The estimated fraction of fire-driven deforestation for different land management categories in this study is likely conservative because satellite platforms do not detect all fires. Satellite sensors may not sample at the peak of diurnal fire activity (Giglio et al., 2000), and cloud obscuration (Giglio et al., 2003) and orbital coverage (Schroeder et al., 2005) reduce the probability of fire detections, particularly for low-latitude regions with persistent cloud cover such as Southeast Asia. New satellite products partially overcome these limitations through improvements in orbital coverage and spatial resolution (Schroeder et al., 2014), especially for detection of small and low-intensity fires in deforestation or peatland areas (Schroeder et al., 2015; Elvidge et al., 2015).

Aligning certification criteria with existing satellite monitoring capabilities could improve the transparency, accountability, and impact of RSPO and other certification efforts. RSPO certification prohibits specific categories of forest clearing that cannot be readily distinguished using satellite data. For example, total forest loss can be identified using freely available satellite data products, but $\mathrm{HCV}$ or primary forest types cannot be confirmed with Landsat or MODIS data. Changing RSPO criteria to more closely match existing satellite data products on forest cover and forest loss would enable more rigorous monitoring of environmental compli- ance. Our study identified forest loss on plantations seeking certification after the cutoff date set by RSPO, but observations of forest loss do not confirm noncompliance with the $\mathrm{P} \& \mathrm{C}$ of certification because HCV and primary forest areas cannot be confirmed using satellite data. Alternatively, public databases of set-aside areas on certified plantations (e.g., stream buffers, areas deemed unsuitable for production, or HCV) could improve transparency and support monitoring efforts without the need to derive forest conditions directly from satellite data. New, higher-resolution active fire data also complement the time series of MODIS active fire observations. Landsat and VIIRS active fire data offer sufficient spatial detail to unambiguously attribute fire activity to specific land owners - an important step forward in satellite monitoring by governments, nongovernmental organizations, or certification bodies such as RSPO. Fire suppression is important to safeguard carbon stocks in peatlands, and Landsat resolution is particularly beneficial for early detection of new wildfires and for identifying small, smouldering fires in peat areas (Schroeder et al., 2015; Elvidge et al., 2015) that may persist for weeks and exacerbate GHG emissions and regional air quality during drought events.

By 2020, Indonesia has pledged to double its palm oil production (Maulia, 2010), and expanding production threatens remaining rainforest and peatland areas. Certification offers a path for low-carbon development of additional oil palm production, provided that certification standards are consistent with capabilities for routine satellite monitoring. RSPO certification has reduced but not eliminated forest loss and fire use on certified plantations. To realize the full potential of certification, requirements for RSPO certification must be updated to align environmental goals with objective measures of compliance, including industry commitments to a goal of zero deforestation. Such transparency would also provide more direct insight into the key mechanisms through which agricultural intensification and expansion contribute to feedbacks in the Earth system.

Data availability. Satellite-based estimates of active fires, forest loss, and land cover for Indonesia, Malaysia, and Papua New Guinea are available online. MODIS active fire data from NASA's Terra and Aqua satellite can be accessed via https://earthdata.nasa.gov/ (NASA, 2016). VIIRS near real-time active fire products are available via https://earthdata.nasa.gov/ and http://viirsfire.geog.umd.edu/ (VIIRS, 2016). Annual estimates of forest cover and forest cover change derived from Landsat data are available from http://glad.umd.edu/ (GLAD, 2015). Land cover maps, including maps of planted palm oil, are available from Global Forest Watch (2014) (http://www.globalforestwatch.org/). Boundaries for certified (partial) palm oil plantations are available upon request from RSPO (2014) (http://www.rspo.org/) and boundaries for noncertified palm oil plantations are available from Greenpeace (2016) (http://www.greenpeace.org/seasia/id/ Global/seasia/Indonesia/Code/Forest-Map/en/index.html) and Sawit Watch (2013) (upon request) (http://sawitwatch.or.id/). 


\section{Appendix A}

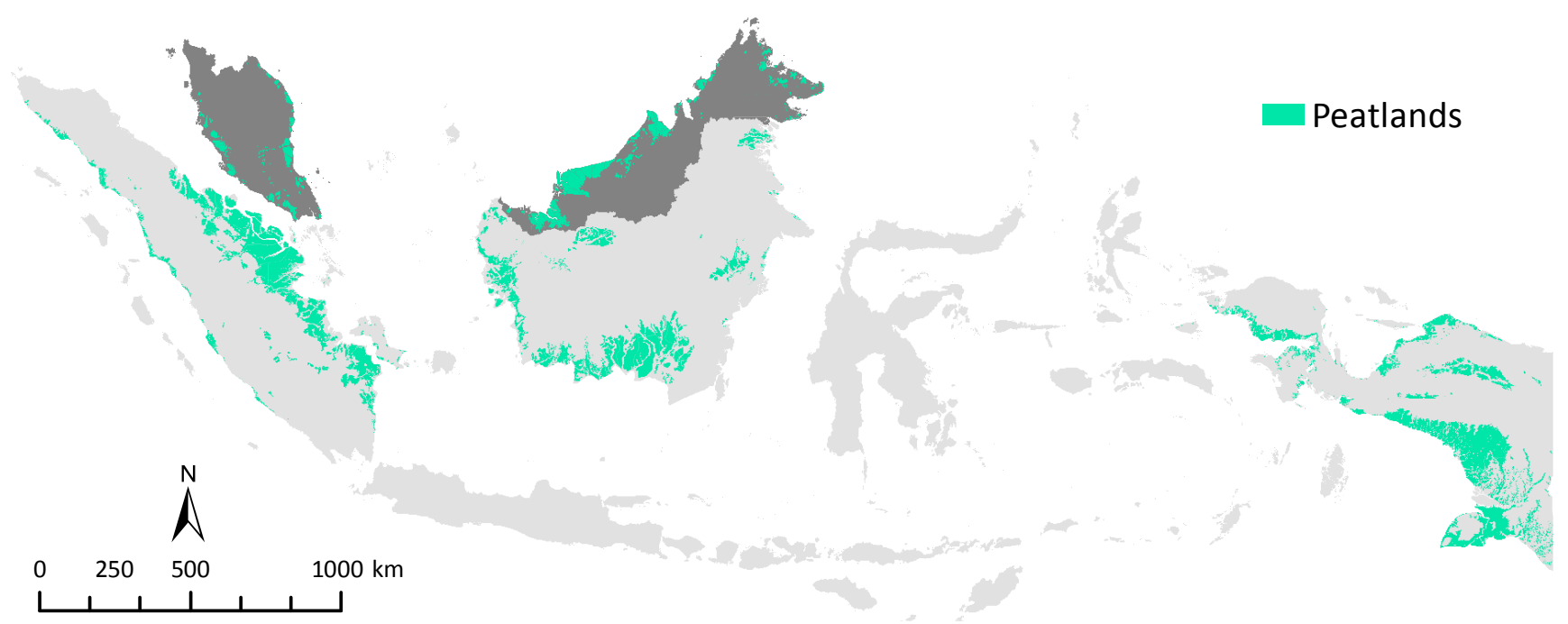

Figure A1. Extent of peatland in Indonesia and Malaysia (Wahyunto and Subagjo, 2003, 2004; Wahyunto et al., 2006 and WI, 2016).

(a)

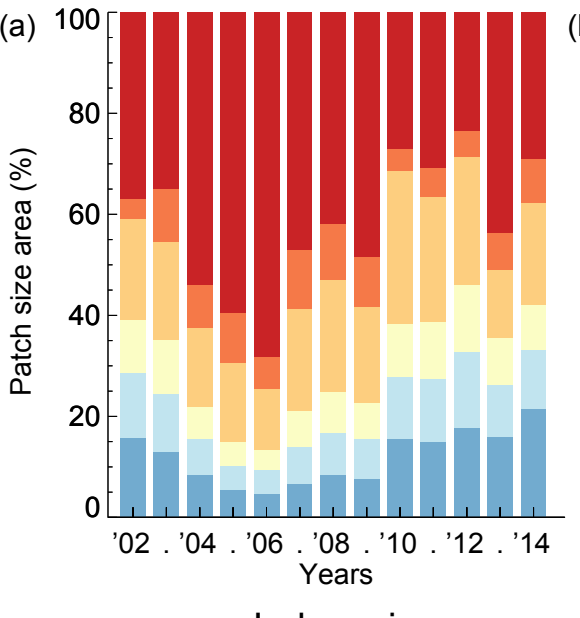

-: Indonesia :- (b)

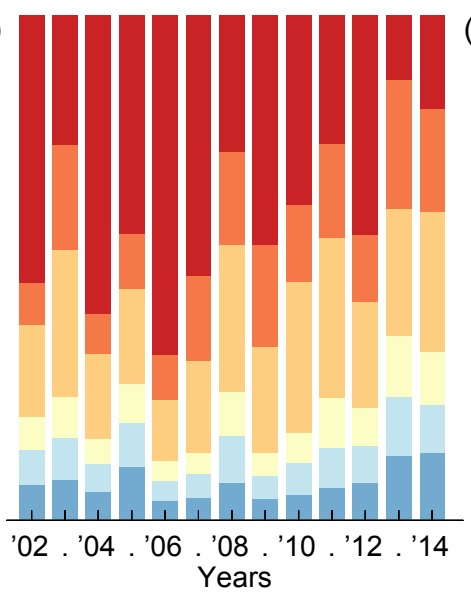

-: Malaysia :- (c)

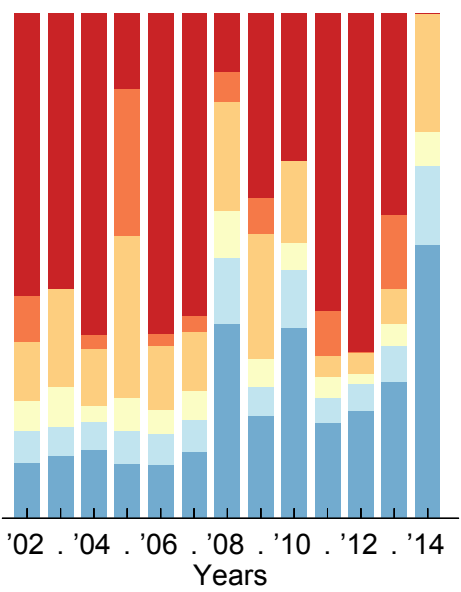

-: Papua New Guinea :-

Patch size (ha)

$\begin{array}{ll}>100 & 5-10 \\ 50-100 & 2-5 \\ 10-50 & 0-2\end{array}$

Figure A2. Forest loss patch size distribution in the RSPO certified plantations of (a) Indonesia, (b) Malaysia, and (c) Papua New Guinea. Patch sizes were assessed at the plantation level and summarized annually based on the proportion of total forest loss in each size class during 2002-2014. 

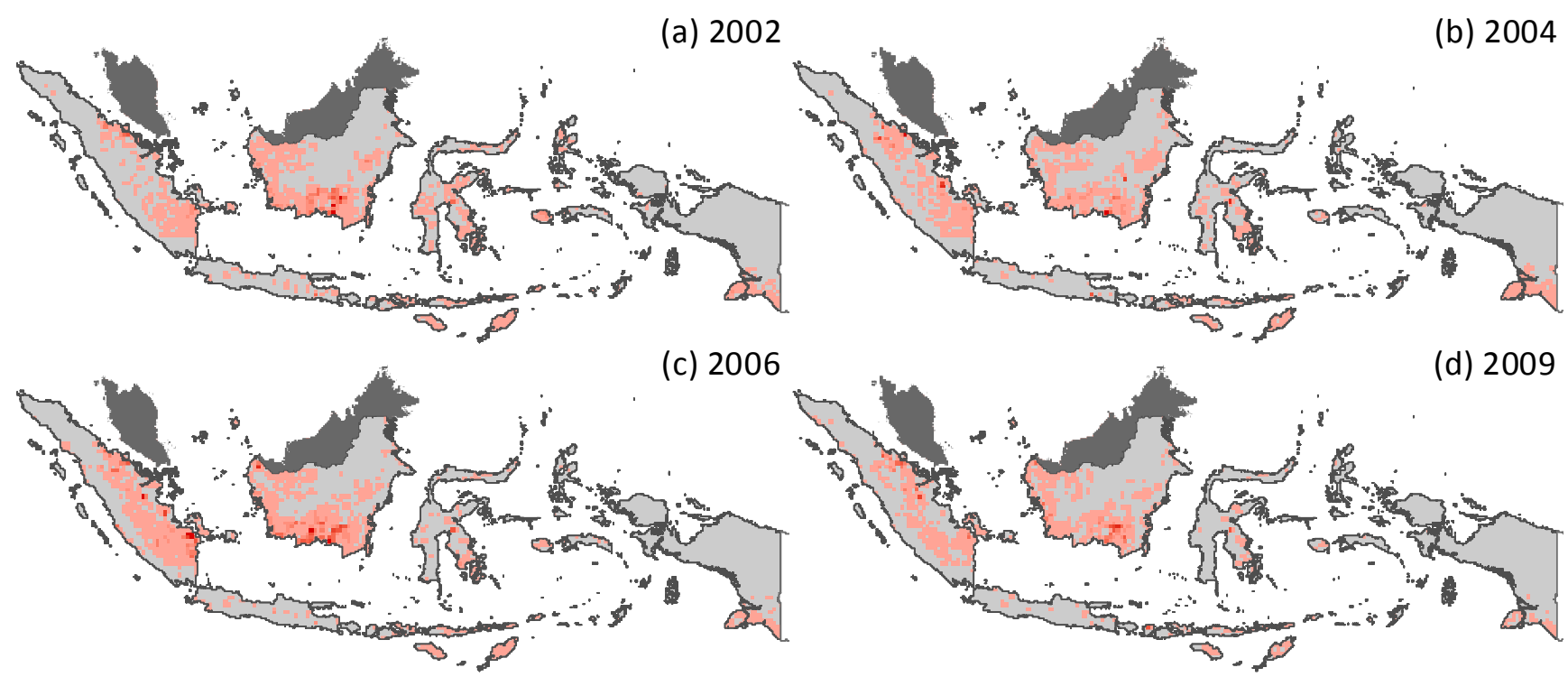

(e) 2013

(f) 2015
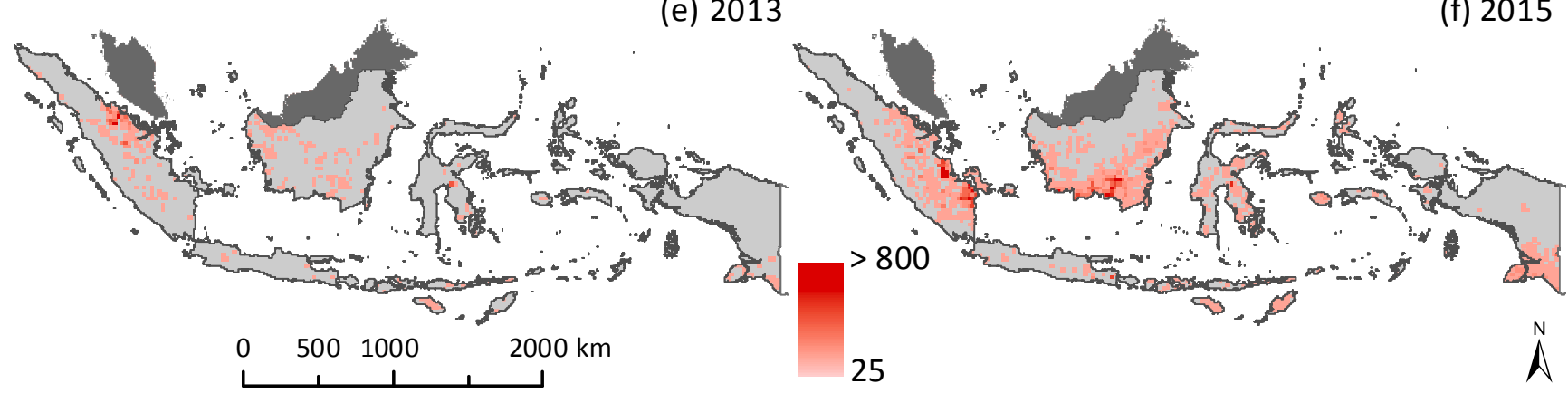

Figure A3. Density of MODIS active fire detections in Indonesia during El Niño years (a-d, f) and the June 2013 drought (e), when fires from Sumatra impacted air quality in Singapore (Gaveau et al., 2014). The spatial distribution of fire activity was consistent during El Niño years, although fire densities were highest in 2006 and 2015. Maps show annual totals of Terra and Aqua MODIS fire detections at $0.25^{\circ}$ resolution. 

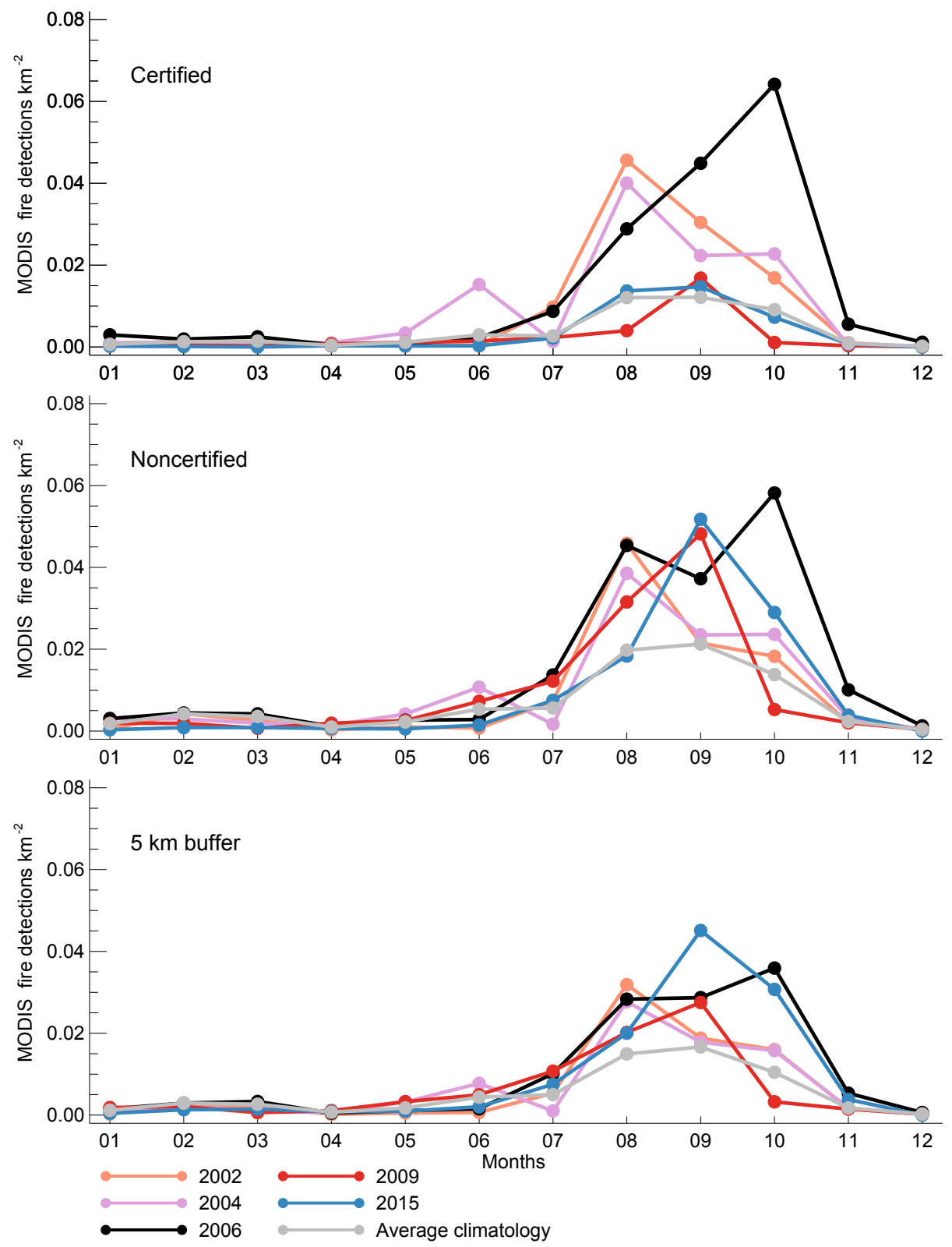

Figure A4. Monthly density of MODIS active fire detections (Terra and Aqua, combined) for certified plantations, noncertified plantations, and a $5 \mathrm{~km}$ buffer region surrounding plantations in Indonesia during El Niño years. A climatology of average monthly fire detections from all years (2001-2015) is shown in grey. 


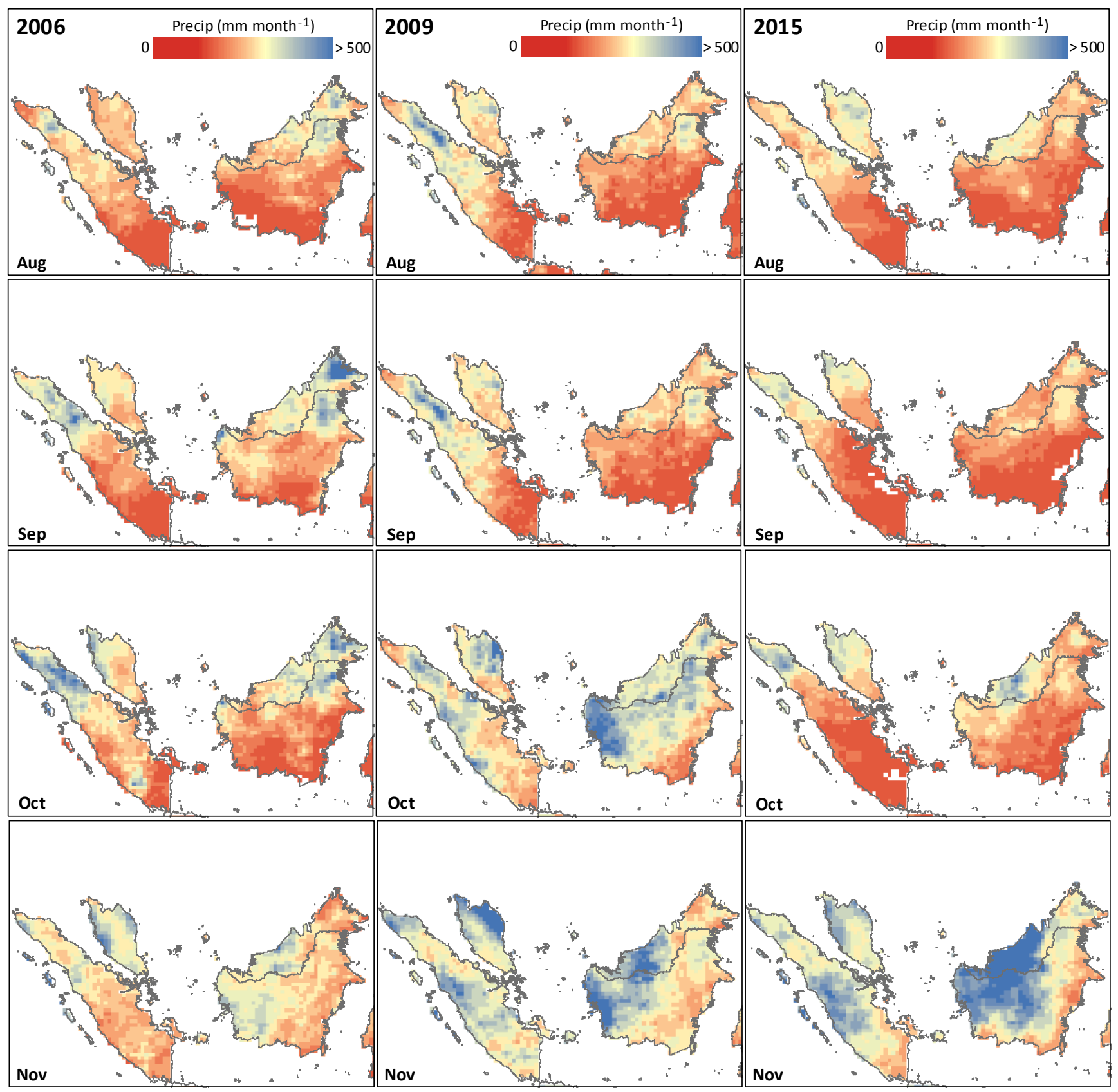

Figure A5. Monthly precipitation patterns for Indonesia and Malaysia from the Tropical Rainfall Measuring Mission (TRMM) at $0.25^{\circ}$ resolution for months with peak fire activity during the 2006, 2009, and 2015 El Niño events. Certified and noncertified plantations are clustered in similar locations (see Fig. 1); $73 \%$ of certified plantations were directly adjacent to one or more noncertified plantations, and $89 \%$ of certified plantations were within $10 \mathrm{~km}$ of a noncertified plantation. Given this clustering, and the spatial resolution of precipitation estimates from the TRMM satellite, we assume that precipitation reductions during El Niño events influence certified and noncertified plantations in a similar fashion. 

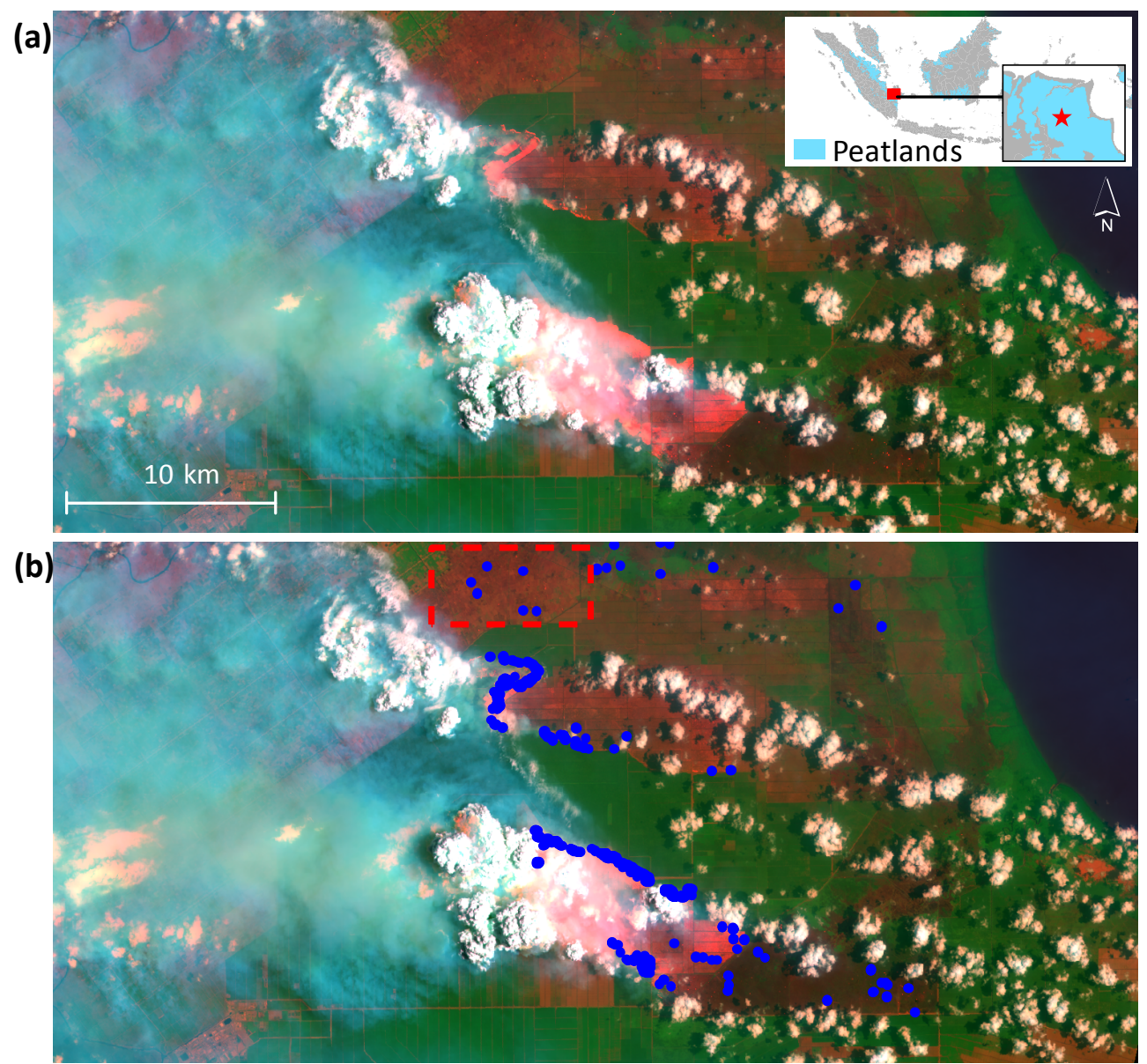

(c)

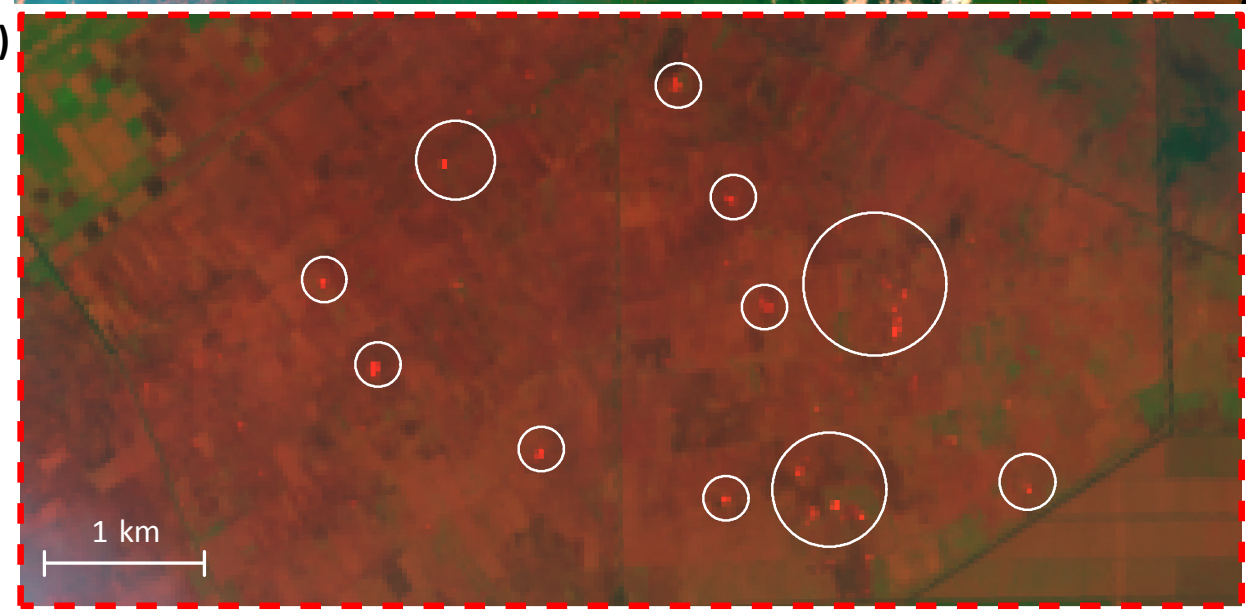

Figure A6. Landsat 8 active fire detections captured active fire fronts (b) and residual smouldering fires (c) in peatland areas of southern Sumatra on 30 September 2015. White circles in (c) indicate smouldering for a subset of the image in (b) (dashed red outline). The regular grid of peatland drainage canals is visible in all panels. 


\section{Appendix B}

Table B1. Total and fire-driven forest loss for oil palm expansion on certified plantations in Indonesia, Malaysia, and Papua New Guinea during 2002-2014. See Tables B2-B5 for annual estimates of total forest loss, fire-driven forest loss, and the proportion of forest losses on plantations after the receipt of RSPO certification. All areas are given in hectares (ha).

\begin{tabular}{lrrrrr}
\hline & $\begin{array}{r}\text { Lease area } \\
(\text { ha) }\end{array}$ & $\begin{array}{r}\text { Planted palm by } 2010^{\mathrm{a}} \\
\text { (ha) }\end{array}$ & $\begin{array}{r}\text { Forest loss } \\
(\text { ha })\end{array}$ & $\begin{array}{r}\text { Peat forest loss } \\
\text { (ha) }\end{array}$ & $\begin{array}{r}\text { Fire-driven loss } \\
\text { (ha) }\end{array}$ \\
\hline Indonesia (IDN) & 1652644 & 1212669 & 267931 & 61750 & $85524(26 \%)$ \\
Malaysia (MYS) & 1113686 & 877629 & 121958 & 5931 & $5925(5 \%)$ \\
Papua New Guinea (PNG) & 174439 & 94001 & 21491 & - & $3860(18 \%)$ \\
\hline
\end{tabular}

${ }^{a}$ Forest loss outside of peat areas. ${ }^{b}$ Combined (peat and non-peat) forest loss related to fire.

Table B2. Total and fire-driven forest loss for oil palm expansion in Indonesia from 2002 to 2014 on the certified and noncertified plantations. The percentage of total forest loss on plantations with RSPO certification is shown beginning in 2009. Totals exclude peat forest loss (see Table B3).

\begin{tabular}{|c|c|c|c|c|c|c|c|c|}
\hline \multirow[b]{2}{*}{ Year } & \multicolumn{4}{|c|}{ Certified } & \multicolumn{2}{|c|}{ Noncertified } & \multicolumn{2}{|c|}{ Buffer $5 \mathrm{~km}$} \\
\hline & $\begin{array}{r}\text { Total } \\
\text { loss (ha) }\end{array}$ & $\begin{array}{r}\text { Post-certification } \\
\text { loss }(\%)\end{array}$ & $\begin{array}{r}\text { Fire-driven } \\
\text { loss (ha) }\end{array}$ & $\begin{array}{r}\text { Post-certification } \\
\text { loss }(\%)\end{array}$ & $\begin{array}{r}\text { Total } \\
\text { loss (ha) }\end{array}$ & $\begin{array}{r}\text { Fire-driven } \\
\text { loss (ha) }\end{array}$ & $\begin{array}{r}\text { Total } \\
\text { loss (ha) }\end{array}$ & $\begin{array}{r}\text { Fire-driven } \\
\text { loss (ha) }\end{array}$ \\
\hline 2002 & 12646 & & 4961 & & 86179 & 21890 & 184140 & 29713 \\
\hline 2003 & 7043 & & 2552 & & 53578 & 18693 & 104882 & 23135 \\
\hline 2004 & 32885 & & 12587 & & 158904 & 62232 & 288634 & 71538 \\
\hline 2005 & 33795 & & 9170 & & 140345 & 42260 & 244178 & 56281 \\
\hline 2006 & 54313 & & 12023 & & 224249 & 85081 & 320690 & 88869 \\
\hline 2007 & 34218 & & 6905 & & 203990 & 61875 & 303782 & 67606 \\
\hline 2008 & 27376 & & 876 & & 252538 & 31337 & 355449 & 47793 \\
\hline 2009 & 29229 & (1) & 2543 & (0) & 335246 & 62356 & 446635 & 79842 \\
\hline 2010 & 6267 & (8) & 306 & (0) & 120598 & 14330 & 228111 & 28634 \\
\hline 2011 & 7105 & (23) & 308 & (42) & 240864 & 22776 & 316644 & 34771 \\
\hline 2012 & 9163 & (25) & 495 & (25) & 334453 & 45787 & 512886 & 80585 \\
\hline 2013 & 6628 & (50) & 480 & (82) & 176080 & 21815 & 245738 & 32635 \\
\hline 2014 & 7264 & (82) & 774 & (96) & 195885 & 31298 & 302012 & 48848 \\
\hline
\end{tabular}


Table B3. Total and fire-driven peat forest loss for oil palm expansion in Indonesia from 2002 to 2014 within certified and noncertified plantations. The percentage of total peat forest loss on plantations with RSPO certification is shown beginning in 2009 , the year plantations in Indonesia were first granted RSPO certificates. See Table B2 for lowland forest loss on mineral soils.

\begin{tabular}{|c|c|c|c|c|c|c|c|c|}
\hline \multirow[b]{2}{*}{ Year } & \multicolumn{4}{|c|}{ Certified } & \multicolumn{2}{|c|}{ Noncertified } & \multicolumn{2}{|c|}{ Buffer $5 \mathrm{~km}$} \\
\hline & $\begin{array}{r}\text { Total } \\
\text { loss (ha) }\end{array}$ & $\begin{array}{r}\text { Post-certification } \\
\text { loss }(\%)\end{array}$ & $\begin{array}{r}\text { Fire-driven } \\
\text { loss (ha) }\end{array}$ & $\begin{array}{r}\text { Post-certification } \\
\text { loss }(\%)\end{array}$ & $\begin{array}{r}\text { Total } \\
\text { loss (ha) }\end{array}$ & $\begin{array}{r}\text { Fire-driven } \\
\text { loss (ha) }\end{array}$ & $\begin{array}{r}\text { Total } \\
\text { loss (ha) }\end{array}$ & $\begin{array}{r}\text { Fire-driven } \\
\text { loss (ha) }\end{array}$ \\
\hline 2002 & 3408 & & 452 & & 26271 & 13496 & 36719 & 14116 \\
\hline 2003 & 1696 & & 1007 & & 17486 & 10393 & 20140 & 10307 \\
\hline 2004 & 6555 & & 3789 & & 47330 & 23756 & 71975 & 30891 \\
\hline 2005 & 7375 & & 4514 & & 56080 & 29196 & 91955 & 45933 \\
\hline 2006 & 18119 & & 4938 & & 45606 & 28978 & 60686 & 31992 \\
\hline 2007 & 9622 & & 2741 & & 63461 & 32638 & 99661 & 47172 \\
\hline 2008 & 4888 & & 350 & & 60468 & 13057 & 65747 & 16117 \\
\hline 2009 & 6632 & (0) & 569 & $(0)$ & 113140 & 44731 & 95858 & 39048 \\
\hline 2010 & 514 & (3) & 121 & $(0)$ & 38743 & 11717 & 70823 & 23902 \\
\hline 2011 & 1429 & (55) & 208 & (89) & 62348 & 15796 & 71104 & 20570 \\
\hline 2012 & 584 & (64) & 80 & (90) & 100402 & 30024 & 120737 & 46583 \\
\hline 2013 & 274 & (55) & 19 & (93) & 50290 & 11431 & 52496 & 18749 \\
\hline 2014 & 654 & (83) & 201 & (96) & 60400 & 23404 & 79305 & 38035 \\
\hline
\end{tabular}

Table B4. Number of certified and noncertified plantations with fire-driven deforestation between 2002 and 2014. Plantations with fire-driven deforestation after receiving RSPO certification are shown in parentheses beginning in 2009 .

\begin{tabular}{rrrr|r}
\hline & \multicolumn{3}{c|}{ Certified } & Noncertified \\
\cline { 2 - 5 } Year & Indonesia & Malaysia & Papua New Guinea & Indonesia \\
& $N=154$ & $N=119$ & $N=10$ & $N=1536$ \\
\hline 2002 & 63 & 20 & 4 & 747 \\
2003 & 64 & 12 & 5 & 733 \\
2004 & 82 & 16 & 4 & 913 \\
2005 & 78 & 18 & 3 & 859 \\
2006 & 67 & 12 & 5 & 927 \\
2007 & 66 & 5 & 5 & 902 \\
2008 & 39 & 8 & 5 & 724 \\
2009 & $50(0)$ & $7(0)$ & $3(0)$ & 886 \\
2010 & $35(1)$ & $10(2)$ & $3(1)$ & 738 \\
2011 & $34(6)$ & $12(5)$ & $2(1)$ & 697 \\
2012 & $36(12)$ & $9(5)$ & $2(1)$ & 783 \\
2013 & $39(17)$ & $8(4)$ & $1(1)$ & 692 \\
2014 & $37(25)$ & $8(6)$ & $2(2)$ & 766 \\
\hline
\end{tabular}


Table B5. Total and fire-driven forest loss for oil palm expansion on certified plantations in Malaysia and Papua New Guinea during 20022014. All areas are given in hectares (ha), and totals exclude peat forest loss (see Table B5). The percentage of total forest loss on plantations with RSPO certification is shown beginning in 2008.

\begin{tabular}{|c|c|c|c|c|c|c|c|c|}
\hline \multirow[b]{2}{*}{ Year } & \multicolumn{4}{|c|}{ Malaysia } & \multicolumn{4}{|c|}{ Papua New Guinea } \\
\hline & $\begin{array}{r}\text { Total } \\
\text { loss (ha) }\end{array}$ & $\begin{array}{r}\text { Post-certification } \\
\text { loss }(\%)\end{array}$ & $\begin{array}{r}\text { Fire-driven } \\
\text { loss (ha) }\end{array}$ & $\begin{array}{r}\text { Post-certification } \\
\text { loss }(\%)\end{array}$ & $\begin{array}{r}\text { Total } \\
\text { loss (ha) }\end{array}$ & $\begin{array}{r}\text { Post-certification } \\
\text { loss }(\%)\end{array}$ & $\begin{array}{r}\text { Fire-driven } \\
\text { loss (ha) }\end{array}$ & $\begin{array}{r}\text { Post-certification } \\
\text { loss (\%) }\end{array}$ \\
\hline 2002 & 14870 & & 912 & & 3959 & & 1244 & \\
\hline 2003 & 6563 & & 791 & & 1645 & & 301 & \\
\hline 2004 & 13522 & & 1912 & & 3279 & & 721 & \\
\hline 2005 & 6410 & & 506 & & 1242 & & 252 & \\
\hline 2006 & 12312 & & 465 & & 2893 & & 718 & \\
\hline 2007 & 12045 & & 15 & & 2099 & & 479 & \\
\hline 2008 & 7381 & (2) & 91 & (0) & 1,188 & (34) & 116 & (7) \\
\hline 2009 & 15467 & (8) & 69 & (0) & 938 & (71) & 3 & (0) \\
\hline 2010 & 10378 & (19) & 155 & (8) & 716 & (85) & 14 & (96) \\
\hline 2011 & 8222 & (35) & 120 & (65) & 1065 & (85) & 4 & (98) \\
\hline 2012 & 7432 & (48) & 235 & (63) & 1235 & (79) & 3 & (77) \\
\hline 2013 & 3261 & $(50)$ & 85 & (78) & 756 & (100) & 0 & (100) \\
\hline 2014 & 4096 & (82) & 114 & (81) & 477 & $(100)$ & 3 & (100) \\
\hline
\end{tabular}

Table B6. Total and fire-driven peat forest loss for oil palm expansion on certified plantations in Malaysia during 2002-2014. All areas are given in hectares (ha). The percentage of total peat forest loss on plantations with RSPO certification is shown beginning in 2008. See Table B4 for lowland forest loss on mineral soils.

\begin{tabular}{rrrrr}
\hline & \multicolumn{4}{c}{ Malaysia } \\
\cline { 2 - 5 } Year & $\begin{array}{r}\text { Total } \\
\text { loss (ha) }\end{array}$ & $\begin{array}{r}\text { Post-certification } \\
\text { loss (\%) }\end{array}$ & $\begin{array}{r}\text { Fire-driven } \\
\text { loss (ha) }\end{array}$ & $\begin{array}{r}\text { Post-certification } \\
\text { loss (\%) }\end{array}$ \\
\hline 2002 & 303 & & 2 & \\
2003 & 97 & & 26 & \\
2004 & 272 & & 0 & \\
2005 & 388 & & 32 & \\
2006 & 210 & & 12 & $(0)$ \\
2007 & 238 & $(5)$ & 0 & $(1)$ \\
2008 & 300 & $(37)$ & 0 & $(91$ \\
2009 & 780 & $(33)$ & 12 & $(0)$ \\
2010 & 1146 & $(35)$ & 15 & $(100)$ \\
2011 & 559 & $(48)$ & 1 & $(100)$ \\
2012 & 1243 & $(58)$ & 8 & \\
2013 & 207 & $(91)$ & 7 & \\
2014 & 187 & & & \\
\hline
\end{tabular}


Table B7. Total MODIS fire detections for certified plantations in Indonesia, Malaysia, and Papua New Guinea. The percentage of fire detections on plantations with RSPO certification is shown for 2008-2015.

\begin{tabular}{|c|c|c|c|c|c|c|}
\hline \multirow[b]{2}{*}{ Year } & \multicolumn{2}{|c|}{ Indonesia } & \multicolumn{2}{|c|}{ Malaysia } & \multicolumn{2}{|c|}{ Papua New Guinea } \\
\hline & $\begin{array}{r}\text { Total fire } \\
\text { detections }\end{array}$ & $\begin{array}{l}\text { Post-certification } \\
\text { fire detection }(\%)\end{array}$ & $\begin{array}{r}\text { Total fire } \\
\text { detections }\end{array}$ & $\begin{array}{r}\text { Post-certification } \\
\text { fire detections }(\%)\end{array}$ & $\begin{array}{r}\text { Total fire } \\
\text { detections }\end{array}$ & $\begin{array}{l}\text { Post-certification } \\
\text { fire detections }(\%)\end{array}$ \\
\hline 2001 & 169 & & 124 & & 37 & \\
\hline 2002 & 1782 & & 87 & & 130 & \\
\hline 2003 & 716 & & 71 & & 64 & \\
\hline 2004 & 1821 & & 87 & & 130 & \\
\hline 2005 & 1008 & & 128 & & 39 & \\
\hline 2006 & 2712 & & 17 & & 83 & \\
\hline 2007 & 197 & & 12 & & 61 & \\
\hline 2008 & 87 & & 9 & (0) & 43 & (7) \\
\hline 2009 & 483 & $(0)$ & 22 & (0) & 31 & (0) \\
\hline 2010 & 72 & (8) & 18 & (28) & 44 & (95) \\
\hline 2011 & 196 & (29) & 12 & $(50)$ & 18 & (67) \\
\hline 2012 & 191 & (39) & 21 & (33) & 44 & (84) \\
\hline 2013 & 128 & (55) & 11 & (55) & 54 & (100) \\
\hline 2014 & 361 & (73) & 35 & (69) & 52 & (100) \\
\hline 2015 & 656 & $(100)$ & 26 & (100) & 136 & (100) \\
\hline
\end{tabular}


Competing interests. The authors declare that they have no conflict of interest.

Acknowledgements. We thank the RSPO Secretariat and Sawit Watch for providing the data. Funding for this study was provided by NASA's Carbon Monitoring System and Interdisciplinary Science Programs and the Norwegian Agency for Development Cooperation's Civil Society Department under Norway's International Climate and Forest Initiative (NORAD, grants QZA-0465 and QZA-13/0075).

Edited by: Somnath Baidya Roy

Reviewed by: Kemen Austin and two anonymous referees

\section{References}

Abood, S. A., Lee, J. S. H., Burivalova, Z., Garcia-Ulloa, J., and Koh, L. P.: Relative Contributions of the Logging, Fiber, Oil Palm, and Mining Industries to Forest Loss in Indonesia, Conservation Letters, 8, 58-67, 2015.

Austin, K. G., Kasibhatla, P. S., Urban, D. L., Stolle, F., and Vincent, J.: Reconciling Oil Palm Expansion and Climate Change Mitigation in Kalimantan, Indonesia, PLoS ONE, 10, e0127963, https://doi.org/10.1371/journal.pone.0127963, 2015.

BP-REDD+: National Forest Reference Emission Level for Deforestation and Forest Degradation in the Context of the Activities Referred to in Decision 1/ CP.16, Paragraph 70 (REDD+) Under the UNFCCC: A Reference for Decision Makers, BP-REDD+ Indonesia, 2015.

Butler, R.: Palm oil major makes deforestation-free commitment, available at: https://news.mongabay.com/2015/02/ palm-oil-major-makes-deforestation-free-commitment/ (last access: 8 September 2016), 2015.

Carlson, K. M., Curran, L. M., Ratnasari, D., Pittman, A. M., Soares-Filho, B. S., Asner, G. P., Trigg, S. N., Gaveau, D. A., Lawrence, D., and Rodrigues, H. O.: Committed carbon emissions, deforestation, and community land conversion from oil palm plantation expansion in West Kalimantan, Indonesia, P. Natl. Acad. Sci. USA, 109, 7559-7564, 2012.

Carlson, K. M., Curran, L. M., Asner, G. P., Pittman, A. M., Trigg, S. N., and Marion Adeney, J.: Carbon emissions from forest conversion by Kalimantan oil palm plantations, Nature Clim. Change, 3, 283-287, 2013.

Cattau, M. E., Marlier, M. E., and DeFries, R.: Effectiveness of Roundtable on Sustainable Palm Oil (RSPO) for reducing fires on oil palm concessions in Indonesia from 2012 to 2015, Environ. Res. Lett., 11, 105007, https://doi.org/10.1088/17489326/11/10/105007, 2016a.

Cattau, M. E., Harrison, M. E., Shinyo, I., Tungau, S., Uriarte, M., and DeFries, R.: Sources of anthropogenic fire ignitions on the peat-swamp landscape in Kalimantan, Indonesia, Global Environ. Chang., 39, 205-219, 2016 b.

Chen, Y., Morton, D. C., Andela, N., Giglio, L., and Randerson, J. T.: How much global burned area can be forecast on seasonal time scales using sea surface temperatures?, Environ. Res. Lett., 11, 045001, https://doi.org/10.1088/17489326/11/4/045001, 2016.
Chisholm, R. A., Wijedasa, L. S., and Swinfield, T.: The need for long-term remedies for Indonesia's forest fires, Conserv. Biol., 30, 5-6, 2016.

DeFries, R. S., Morton, D. C., van der Werf, G. R., Giglio, L., Collatz, G. J., Randerson, J. T., Houghton, R. A., Kasibhatla, P. K., and Shimabukuro, Y.: Fire-related carbon emissions from land use transitions in southern Amazonia, Geophys. Res. Lett., 35, L22705, https://doi.org/10.1029/2008GL035689, 2008.

Edwards, S. and Heiduk, F.: Hazy Days: Forest Fires and the Politics of Environmental Security in Indonesia, Journal Of Current Southeast Asian Affairs, 34, 65-94, 2015.

Elvidge, C. D., Zhizhin, M., Hsu, F.-C., Baugh, K., Khomarudin, M. R., Vetrita, Y., Sofan, P., and Hilman, D.: Long-wave infrared identification of smoldering peat fires in Indonesia with nighttime Landsat data, Environ. Res. Lett., 10, 065002, https://doi.org/10.1088/1748-9326/10/6/065002, 2015.

FAO: Global forest resources assessment 2010, FAO Forestry Paper, 163, available at: http://www.fao.org/docrep/013/i1757e/i1757e. pdf (last access: August 2016), Rome, Food and Agriculture Organization of the United Nations, 2010.

FAO: FAOSTAT Online Statistical Service, available at: http:// faostat3.fao.org/, last access: June 2016.

Field, R. D., van der Werf, G. R., and Shen, S. S. P.: Human amplification of drought-induced biomass burning in Indonesia since 1960, Nat. Geosci., 2, 185-188, 2009.

Field, R. D., van der Werf, G. R., Fanin, T., Fetzer, E. J., Fuller, R., Jethva, H., Levy, R., Livesey, N. J., Luo, M., Torres, O., and Worden, H. M.: Indonesian fire activity and smoke pollution in 2015 show persistent nonlinear sensitivity to El Niñoinduced drought, P. Natl. Acad. Sci. USA, 113, 9204-9209, https://doi.org/10.1073/pnas.1524888113, 2016.

Garrett, R. D., Carlson, K. M., Rueda, X., and Noojipady, P.: Assessing the potential additionality of certification by the Round table on Responsible Soybeans and the Roundtable on Sustainable Palm Oil, Environ. Res. Lett., 11, 045003, https://doi.org/10.1088/1748-9326/11/4/045003, 2016.

Gaveau, D. L. A., Salim, M. A., Hergoualc'h, K., Locatelli, B., Sloan, S., Wooster, M., Marlier, M. E., Molidena, E., Yaen, H., DeFries, R., Verchot, L., Murdiyarso, D., Nasi, R., Holmgren, P., and Sheil, D.: Major atmospheric emissions from peat fires in Southeast Asia during non-drought years: evidence from the 2013 Sumatran fires, Scientific Reports, 4, 6112, https://doi.org/10.1038/srep06112, 2014.

Gaveau, D. L. A., Sheil, D., Husnayaen, Salim, M. A., Arjasakusuma, S., Ancrenaz, M., Pacheco, P., and Meijaard, E.: Rapid conversions and avoided deforestation: examining four decades of industrial plantation expansion in Borneo, Scientific Reports, 6, 32017, https://doi.org/10.1038/srep32017, 2016.

Giglio, L., Kendall, J. D., and Tucker, C. J.: Remote sensing of fires with the TRMM VIRS, Int. J. Remote Sens., 21, 203-207, 2000.

Giglio, L., Descloitres, J., Justice, C. O., and Kaufman, Y. J.: An enhanced contextual fire detection algorithm for MODIS, Remote Sens. Environ., 87, 273-282, 2003.

GLAD: Global Land Analysis \& Discovery group, Department of Geographical Sciences, University of Maryland, Global Forest Change 2000-2014, available at: http://glad.umd.edu/ (last access: June 2016), 2015.

Global Forest Watch: Tree plantations, available at: http://www. globalforestwatch.org/ (last access: January 2017), 2014. 
Greenpeace: Palm Oil Concessions, available at: http: //www.greenpeace.org/seasia/id/Global/seasia/Indonesia/Code/ Forest-Map/en/index.html, last access: October 2016.

Gunarso, P., Hartoyo, M., Agus, F., and Killeen, T.: Oil palm and land use change in Indonesia, Malaysia and Papua New Guinea, Reports from the Technical Panels of the 2nd greenhouse gas working Group of the Roundtable on Sustainable Palm Oil (RSPO), 29-64, 2013.

Hansen, M. C., Potapov, P. V., Moore, R., Hancher, M., Turubanova, S. A., Tyukavina, A., Thau, D., Stehman, S. V., Goetz, S. J., Loveland, T. R., Kommareddy, A., Egorov, A., Chini, L., Justice, C. O., and Townshend, J. R. G.: High-Resolution Global Maps of 21st-Century Forest Cover Change, Science, 342, 850-853, 2013.

Hooijer, A., Page, S., Jauhiainen, J., Lee, W. A., Lu, X. X., Idris, A., and Anshari, G.: Subsidence and carbon loss in drained tropical peatlands, Biogeosciences, 9, 1053-1071, https://doi.org/10.5194/bg-9-1053-2012, 2012.

Houghton, R. and Hackler, J.: Emissions of carbon from forestry and land-use change in tropical Asia, Glob. Change Biol., 5, 481492, 1999.

Houghton, R. A., House, J. I., Pongratz, J., van der Werf, G. R., DeFries, R. S., Hansen, M. C., Le Quéré, C., and Ramankutty, N.: Carbon emissions from land use and land-cover change, Biogeosciences, 9, 5125-5142, https://doi.org/10.5194/bg-9-51252012, 2012.

Huijnen, V., Wooster, M. J., Kaiser, J. W., Gaveau, D. L. A., Flemming, J., Parrington, M., Inness, A., Murdiyarso, D., Main, B., and van Weele, M.: Fire carbon emissions over maritime southeast Asia in 2015 largest since 1997, Scientific Reports, 6, 26886, https://doi.org/10.1038/srep26886, 2016.

Johnston, F. H., Henderson, S. B., Chen, Y., Randerson, J. T., Marlier, M., DeFries, R. S., Kinney, P., Bowman, D. M., and Brauer, M.: Estimated global mortality attributable to smoke from landscape fires, University of British Columbia, 2015.

Kim, D.-H., Sexton, J. O., and Townshend, J. R.: Accelerated deforestation in the humid tropics from the 1990s to the 2000s, Geophys. Res. Lett., 42, 3495-3501, 2015.

Koh, L. P., Miettinen, J., Liew, S. C., and Ghazoul, J.: Remotely sensed evidence of tropical peatland conversion to oil palm, $\mathrm{P}$. Natl. Acad. Sci. USA, 108, 5127-5132, 2011.

Kunii, O., Kanagawa, S., Yajima, I., Hisamatsu, Y., Yamamura, S., Amagai, T., and Ismail, I. T. S.: The 1997 Haze Disaster in Indonesia: Its Air Quality and Health Effects, Arch. Environ. Health, 57, 16-22, 2002.

Lambin, E. F., Gibbs, H. K., Ferreira, L., Grau, R., Mayaux, P., Meyfroidt, P., Morton, D. C., Rudel, T. K., Gasparri, I., and Munger, J.: Estimating the world's potentially available cropland using a bottom-up approach, Global Environ. Chang., 23, 892901, 2013.

Le Quéré, C., Moriarty, R., Andrew, R. M., Peters, G. P., Ciais, P., Friedlingstein, P., Jones, S. D., Sitch, S., Tans, P., Arneth, A., Boden, T. A., Bopp, L., Bozec, Y., Canadell, J. G., Chini, L. P., Chevallier, F., Cosca, C. E., Harris, I., Hoppema, M., Houghton, R. A., House, J. I., Jain, A. K., Johannessen, T., Kato, E., Keeling, R. F., Kitidis, V., Klein Goldewijk, K., Koven, C., Landa, C. S., Landschützer, P., Lenton, A., Lima, I. D., Marland, G., Mathis, J. T., Metzl, N., Nojiri, Y., Olsen, A., Ono, T., Peng, S., Peters, W., Pfeil, B., Poulter, B., Raupach, M. R., Regnier, P., Rö- denbeck, C., Saito, S., Salisbury, J. E., Schuster, U., Schwinger, J., Séférian, R., Segschneider, J., Steinhoff, T., Stocker, B. D., Sutton, A. J., Takahashi, T., Tilbrook, B., van der Werf, G. R., Viovy, N., Wang, Y.-P., Wanninkhof, R., Wiltshire, A., and Zeng, N.: Global carbon budget 2014, Earth Syst. Sci. Data, 7, 47-85, https://doi.org/10.5194/essd-7-47-2015, 2015.

Margono, B. A., Potapov, P. V., Turubanova, S., Stolle, F., and Hansen, M. C.: Primary forest cover loss in Indonesia over 20002012, Nature Clim. Change, 4, 730-735, 2014.

Marlier, M. E., DeFries, R. S., Kim, P. S., Koplitz, S. N., Jacob, D. J., Mickley, L. J., and Myers, S. S.: Fire emissions and regional air quality impacts from fires in oil palm, timber, and logging concessions in Indonesia, Environ. Res. Lett., 10, 085005, https://doi.org/10.1088/1748-9326/10/8/085005, 2015.

Maulia, E.: Indonesia pledges to "feed the world", Jakarta, Indonesia: TheJakartaPost, available at: http://www.thejakartapost com/news/2010/01/30/indonesia-pledges-feed-world039.html (last access: 28 July 2016), 2010.

McCarthy, B., Rothrock, P., Leonard, J., and Donofrio, S.: Supply Change: Tracking Corporate Commitments to Deforestation-free Supply Chains, Washington DC, Forest Trends, 2016.

Miettinen, J., Hooijer, A., Wang, J., Shi, C., and Liew, S. C.: Peatland degradation and conversion sequences and interrelations in Sumatra, Reg. Environ. Change, 12, 729-737, 2012.

Miettinen, J., Shi, C., and Liew, S. C.: 2015 Land cover map of Southeast Asia at $250 \mathrm{~m}$ spatial resolution, Remote Sensing Letters, 7, 701-710, $2016 \mathrm{a}$.

Miettinen, J., Shi, C., and Liew, S. C.: Land cover distribution in the peatlands of Peninsular Malaysia, Sumatra and Borneo in 2015 with changes since 1990, Global Ecology and Conservation, 6, 67-78, 2016b.

MoF: Reducing Emissions from Deforestation and Forest Degradation in Indonesia, Ministry of Forestry of Indonesia - IFCA (Indonesian Forest Climate Alliance) Consolidation Report, Jakarta, Forestry Research and Development Agency FORDA, 2008.

Morton, D. C., Defries, R. S., Randerson, J. T., Giglio, L., Schroeder, W., and Van Der Werf, G. R.: Agricultural intensification increases deforestation fire activity in Amazonia, Glob. Change Biol., 14, 2262-2275, 2008.

Murdiyarso, D., Lebel, L., Gintings, A. N., Tampubolon, S. M. H., Heil, A., and Wasson, M.: Policy responses to complex environmental problems: insights from a science-policy activity on transboundary haze from vegetation fires in Southeast Asia, Agr. Ecosyst. Environ., 104, 47-56, 2004.

NASA: The National Aeronautics and Space Administration, Active Fire Data, available at: https://earthdata.nasa.gov/, last access: November 2016.

Page, S. E. and Hooijer, A.: 2016. In the line of fire: the peatlands of Southeast Asia, Philos. T. R. Soc. B, 371, 1-9, https://doi.org/10.1098/rstb.2015.0176, 2016.

Page, S. E., Siegert, F., Rieley, J. O., Boehm, H.-D. V., Jaya, A., and Limin, S.: The amount of carbon released from peat and forest fires in Indonesia during 1997, Nature, 420, 61-65, 2002.

Petersen, R., Goldman, E., Harris, N., Sargent, S., Aksenov, D., Manisha, A., Esipova, E., Shevade, V., Loboda, T., and Kuksina, N.: Mapping tree plantations with multispectral imagery: preliminary results for seven tropical countries, World Resources Institute, Washington, DC, 2016. 
Pimm, S. L., Jenkins, C. N., Abell, R., Brooks, T. M., Gittleman, J. L., Joppa, L. N., Raven, P. H., Roberts, C. M., and Sexton, J. O.: The biodiversity of species and their rates of extinction, distribution, and protection, Science, 344, 1246752, https://doi.org/10.1126/science.1246752, 2014.

Potts, J., Lynch, M., Wilkings, A., Huppé, G., Cunningham, M., and Voora, V.: The state of sustainability initiatives review 2014: Standards and the green economy, International Institute for Sustainable Development (IISD) and the International Institute for Environment and Development (IIED), 2014.

Ramdani, F. and Hino, M.: Land use changes and GHG emissions from tropical forest conversion by oil palm plantations in Riau Province, Indonesia, PloS one, 8, e70323, https://doi.org/10.1371/journal.pone.0070323, 2013.

Randerson, J. T., Chen, Y., van der Werf, G. R., Rogers, B. M., and Morton, D. C.: Global burned area and biomass burning emissions from small fires, J. Geophys. Res.-Biogeo., 117, G04012, https://doi.org/10.1029/2012JG002128, 2012.

Reddington, C., Yoshioka, M., Balasubramanian, R., Ridley, D., Toh, Y., Arnold, S., and Spracklen, D.: Contribution of vegetation and peat fires to particulate air pollution in Southeast Asia, Environ. Res. Lett., 9, 094006, https://doi.org/10.1088/17489326/9/9/094006, 2014.

RSPO: Roundtable on Sustainable Palm Oil, Oil Palm Concessions, available at: http://www.rspo.org (last access: September 2016), 2014.

RSPO: RSPO Principles and Criteria for Sustainable Palm Oil Production, available at: http://www.rspo.org/file/RSPO\% 20Principles\%20\&\%20Criteria\%20Document.pdf (last access: September 2016), 2007.

RSPO: Roundtable on Sustainable Palm Oil-Principles and Criteria for Sustainable Palm Oil Production, available at: http://www.rspo.org/key-documents/certification/ rspo-principles-and-criteria (last access: September 2016), 2013.

RSPO: Annual Communications Of Progress, available at: http: //www.rspo.org/members/acop (last access: September 2016), 2015a.

RSPO: Code of Conduct for Members 2015, Membership documents, available at: http://www.rspo.org/key-documents/ membership (last access: August 2016), 2015b.

RSPO: IMPACTS, available at: http://www.rspo.org/about/impacts (last access: June 2017), 2016.

Sawit Watch: Oil palm concessions in Indonesia, available at: http: //sawitwatch.or.id/ (last access: August 2016), 2013.

Schroeder, W., Morisette, J. T., Csiszar, I., Giglio, L., Morton, D., and Justice, C. O.: Characterizing Vegetation Fire Dynamics in Brazil through Multisatellite Data: Common Trends and Practical Issues, Earth Interactions, 9, 1-26, 2005.

Schroeder, W., Oliva, P., Giglio, L., and Csiszar, I. A.: The New VIIRS $375 \mathrm{~m}$ active fire detection data product: Algorithm description and initial assessment, Remote Sens. Environ., 143, 85-96, 2014.

Schroeder, W., Oliva, P., Giglio, L., Quayle, B., Lorenz, E., and Morelli, F.: Active fire detection using Landsat8/OLI data, Remote Sens. Environ., 185, 210-220, https://doi.org/10.1016/j.rse.2015.08.032, 2015.

Sexton, J. O., Noojipady, P., Song, X.-P., Feng, M., Song, D.-X., Kim, D.-H., Anand, A., Huang, C., Channan, S., Pimm, S. L., and Townshend, J. R.: Conservation policy and the measurement of forests, Nature Clim. Change, 6, 192-196, 2016.

Stolle, F., Chomitz, K. M., Lambin, E. F., and Tomich, T. P.: Land use and vegetation fires in Jambi Province, Sumatra, Indonesia, Forest Ecol. Manag., 179, 277-292, 2003.

TW: Transparent World-Tree Plantations, World Resources Institute: Global Forest Watch, available at: http://data.globalforestwatch.org/datasets/ baae47df61ed4a73a6f54f00cb4207e0_5 (last access: 9 December 2016), 2015.

UNCS: FORESTS, Action Statements and Action Plans, United Nations Climate Summit, New York, NY, United Nations, 2014.

UNFCCC: Seventh Session of the Conference of Parties (COP7)/Fifteenth Sessions of the Subsidiary Bodies, Conference of the Parties, Marrakech, Morocco United Nations, 2002.

USDA: INDONESIA: Palm Oil Production Growth To Continue, Commodity Intelligence Report, Washington DC, 2009.

USDA: INDONESIA: Rising Global Demand Fuels Palm Oil Expansion, Commodity Intelligence Report, Washington DC, United States Department of Agriculture - Foreign Agricultural Service, 2010.

USDA: Oilseeds: World Markets and Trade, Washington DC, United States Department of Agriculture-Foreign Agricultural Service, 2016.

van der Werf, G. R., Dempewolf, J., Trigg, S. N., Randerson, J. T., Kasibhatla, P. S., Giglio, L., Murdiyarso, D., Peters, W., Morton, D. C., Collatz, G. J., Dolman, A. J., and DeFries, R. S.: Climate regulation of fire emissions and deforestation in equatorial Asia, P. Natl. Acad. Sci. USA, 105, 20350-20355, 2008.

van der Werf, G. R., Morton, D. C., DeFries, R. S., Giglio, L., Randerson, J. T., Collatz, G. J., and Kasibhatla, P. S.: Estimates of fire emissions from an active deforestation region in the southern Amazon based on satellite data and biogeochemical modelling, Biogeosciences, 6, 235-249, https://doi.org/10.5194/bg6-235-2009, 2009a.

van der Werf, G. R., Morton, D. C., DeFries, R. S., Olivier, J. G. J., Kasibhatla, P. S., Jackson, R. B., Collatz, G. J., and Randerson, J. T.: $\mathrm{CO}_{2}$ emissions from forest loss, Nature Geosci., 2, 737-738, 2009b.

VIIRS: Visible Infrared Imaging Radiometer Suite, Department of Geographical Sciences, University of Maryland, VIIRS Active Fire Detection, available at: http://viirsfire.geog.umd.edu/, last access: November 2016.

Vijay, V., Pimm, S. L., Jenkins, C. N., and Smith, S. J.: The Impacts of Oil Palm on Recent Deforestation and Biodiversity Loss, PLoS ONE, 11, e0159668, https://doi.org/ 10.1371/journal.pone.0159668, 2016.

Wahyunto, R. and Subagjo, H.: Peta Luas Sebaran Lahan Gambut dan Kandungan Karbon di Pulau Sumatera/Maps of Area of Peatland Distribution and Carbon Content in Sumatera, 1990-2002, Bogor, Indonesia, 2003.

Wahyunto, R. S. and Subagjo, H.: Peta Luas Sebaran Lahan Gambut dan Kandungan Karbon di Pulau Kalimantan/Maps of Area of Peatland Distribution and Carbon Content in Kalimantan, 20002002, Bogor, Indonesia, 2004.

Wahyunto, B. H., Bekti, H., and Widiastuti, F.: Peta-Peta Sebaran Lahan Gambut, Luas dan Kandungan Karbon di Papua/Maps of Peatland Distribution, Area and Carbon Content in Papua, 20002001, Bogor, Indonesia, 2006. 
WI: Malaysia Peat Lands, available at: http://gfw2-data.s3. amazonaws.com/country/mys/zip/mys_peat_lands.zip, 2016. 